\title{
Public and Private Enforcement of Securities Laws: Resource-Based Evidence
}

\section{Citation}

Mark Roe \& Howell Jackson, Public and Private Enforcement of Securities Laws: ResourceBased Evidence, 93 J. Fin. Econ. 207 (2009).

\section{Published Version}

http://ac.els-cdn.com/S0304405X09000786/1-s2.0-S0304405X09000786-main.pdf?

\section{Permanent link}

http://nrs.harvard.edu/urn-3:HUL.InstRepos:30068597

\section{Terms of Use}

This article was downloaded from Harvard University's DASH repository, and is made available under the terms and conditions applicable to Open Access Policy Articles, as set forth at http:// nrs.harvard.edu/urn-3:HUL.InstRepos:dash.current.terms-of-use\#OAP

\section{Share Your Story}

The Harvard community has made this article openly available.

Please share how this access benefits you. Submit a story.

Accessibility 
ISSN 1936-5349 (print)

ISSN 1936-5357 (online)

\title{
HARVARD
}

JOHN M. OLIN CENTER FOR LAW, ECONOMICS, AND BUSINESS

\author{
PUBLIC AND PRIVATE ENFORCEMENT \\ OF SECURITIES LAWS: RESOURCE-BASED \\ EVIDENCE
}

Mark Roe and Howell E. Jackson

Discussion Paper No. 638

$4 / 2009$

Harvard Law School

Cambridge, MA 02138

This paper can be downloaded without charge from:

The Harvard John M. Olin Discussion Paper Series:

http://www.law.harvard.edu/programs/olin_center/

The Social Science Research Network Electronic Paper Collection:

http://papers.ssrn.com/abstract_id=\#\#\#\#\#\#

This paper is also a discussion paper of the

John M. Olin Center's Program on Corporate Governance. 


\title{
Public and private enforcement of securities laws: Resource-based evidence
}

\author{
Howell E. Jackson \& Mark J. Roe*
}

March 16, 2009

\begin{abstract}
Ascertaining which enforcement mechanisms work to protect investors has been both a focus of recent work in academic finance and an issue for policy-making at international development agencies. According to recent academic work, private enforcement of investor protection via both disclosure and private liability rules goes hand in hand with financial market development, but public enforcement fails to correlate with financial development and, hence, is unlikely to facilitate it. Our results confirm the disclosure result but reverse the results on both liability standards and public enforcement. We use securities regulators' resources to proxy for regulatory intensity of the securities regulator. When we do, financial depth regularly, significantly, and robustly correlates with stronger public enforcement. In horse races between these resource-based measures of public enforcement intensity and the most common measures of private enforcement, public enforcement is overall as important as disclosure in explaining financial market outcomes around the world and more important than private liability rules. Hence, policymakers who reject public enforcement as useful for financial market development are ignoring the best currently-available evidence.
\end{abstract}

Keywords: Investor protection; Enforcement; Securities regulation; Financial development JEL classification: D21; G14; G18; G24; G28; G32; G34; G38; K22

*Harvard University; hjackson@1aw.harvard.edu; mroe@law.harvard.edu. Harvard Law School’s John M. Olin Center for Law, Economics, and Business, the Leeds Research Fund, and the Ewing Marion Kauffman Foundation supported this work. Michelle Ahmadian, Jean-Denis Greze, and John Horsfield-Bradbury provided valuable research assistance and we received helpful comments from Jennifer Arlen, Lucian Bebchuk, Utpal Bhattacharya, John Coates, Jack Coffee, Eilis Ferran, Allen Ferrell, Jill Fisch, Fritz Foley, Charles Goodhart, Klaus Hopt, Simon Johnson, Christine Jolls, Louis Kaplow, Jonathon Karpoff, Mark Ramseyer, Andrei Shleifer, Jordan Siegel, Gustav Sigurdsson, Holger Spamann, Matthew Stevenson, Lucian Taylor, Michael Wachter, Geoffrey Wood, and participants in workshops at Columbia and Harvard Law Schools, the London Financial Regulation Seminar, the National Bureaus of Economic Research, Wharton, Freshfields' London securities group, and the Max Planck Institute, as well three anonymous referees and the editor. We thank Simeon Djankov and members of the World Bank staff for making available advance copies of their finance database, as well as Andrei Shleifer and co-authors for making their data available. 


\title{
Public and Private Enforcement of Securities Laws: Resource-Based Evidence
}

\author{
Howell E. Jackson \& Mark J. Roe
}

1. Introduction... 1

2. Public and Private Enforcement in Prior Legal Analyses....................................................................... 5

3. Data Description: Measuring Public Enforcement via Regulators' Staffing and Budgetary Resources................ 8

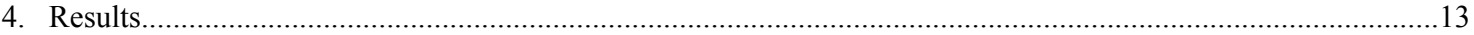

4.1. Replicating La Porta et al. (2006), but with Resource-Based Public Enforcement Measures .......................13

4.2. Public Enforcement, Controlling for Private Enforcement ......................................................................14

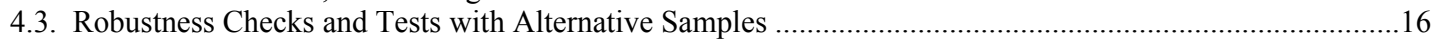

4.4. Financial Variables Associated with Dispersed Ownership ................................................................22

4.5. Limits to Both Private and Public Enforcement: Intermediate Financial Variables .................................21

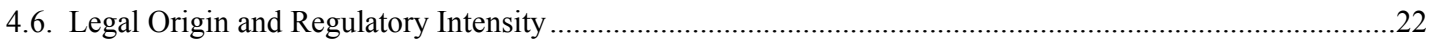

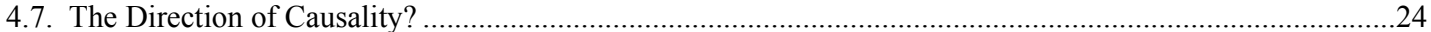

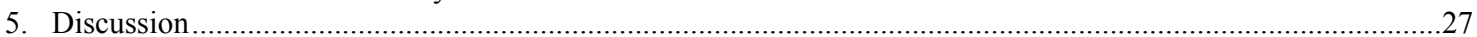

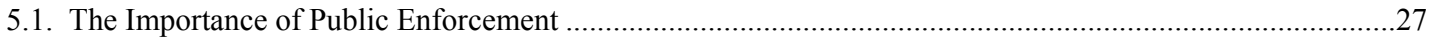

5.2. Channels from Public Enforcement to Financial Outcomes........................................................................28

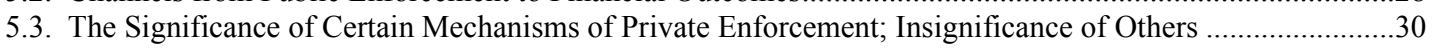

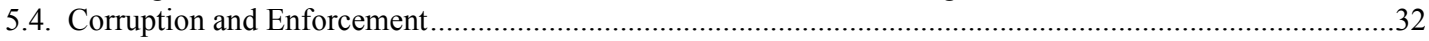

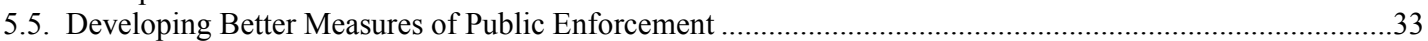

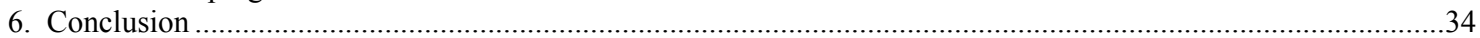

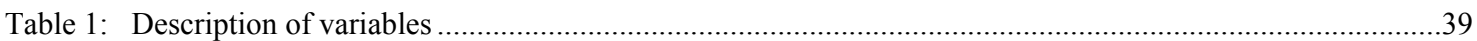

Table 2: Resource-based securities law enforcement data: staffing/population and budget/GDP.........................41

Table 3: Pair-wise correlation matrix for key enforcement variables.................................................................42

Table 4: Resource-based enforcement and formal powers-based enforcement as predicting financial market size

Table 5: Staffing/population-based public enforcement in horse race with private enforcement............................44

Table 6: Budget/GDP-based public enforcement in horse race with private enforcement ......................................46

Table 7: Distribution of coefficients on public enforcement and private enforcement variables in predicting four financial market size outcomes, when winsorizing and using robust regressions...............47

Table 8: Regressions with dependent variables associated with private control ..................................................48

Table 9: Regressions with new World Bank indices as dependent variables ......................................................49

Table 10: Distribution of coefficients on common law dummy, after controlling for public and private enforcement measures.

Figure 1. Residual plot of financial market size on securities regulator staffing (extended sample).......................51

Figure 2. Residual plot of financial market size on securities regulator budget (extended sample) 


\section{Introduction}

We evaluate the value of public enforcement of securities law for the development of stock markets around the world. Properly assessing the value of public and private enforcement has major implications both for the academic understanding of what strengthens financial markets and for the content of current development programs. The World Bank, for example, in seeking to strengthen financial markets and propel economic growth, has recently dismissed public enforcement of securities laws as being unimportant, while seeing private enforcement as central, conclusions we see as having been reached too hastily. The World Bank (2006b, p. 1, 5-6), Djankov et al. (2008, p. 436-437), and La Porta et al. (2006, p. 2) highlight the significance of evaluating the relative importance of private enforcement versus public enforcement of securities obligations that protect investors. Our results indicate that their analyses underestimate the extent to which robust public enforcement is associated with capital market development.

In principle, both enforcement mechanisms could have serious defects and strong advantages. On the defect side: A public enforcement system is degraded because public actors have mixed and often weak incentives to do their jobs well and because they often suffer from poor information of both general market and specific firm conditions. But a private enforcement system is subject to collective action and free rider effects among dispersed investors, to slow and inept judiciaries, to lawyers' rent-seeking, and to the potential inability of private enforcement to visit severe monetary penalties on wrongdoers. On the positive side, public enforcement could be run by public-regarding policymakers and invoke sharp criminal, financial, and reputational penalties that deter egregious wrongdoing, while private enforcement actions could be brought by well-informed actors with well-aligned incentives.

There is no obvious a priori winner. Hence, we seek to evaluate whether public enforcement could, in practice, be valuable by using a new data set of the resources devoted to securities market oversight around the world - resources measured by the staffing levels of securities regulators and by their budgets. Prior studies relied on indices based on the formal powers of regulatory officials to measure the strength 
of public enforcement, a measure that may well be inferior in proxying for effective public enforcement than money and people.

In Section 2, we discuss legal academic analyses on why private lawsuits - a key component of private enforcement emphasized in prior work — often do not penalize the relevant actors, can distort incentives, and can be inefficacious. Because the real world's on-the-ground private enforcement is often misdirected, even suboptimal public enforcement can contribute to good financial outcomes. Although public authorities lack ideal incentives and may be more poorly informed than private actors, the common structures of private lawsuits also yield poor incentives and weak information for the relevant private actors. Good public enforcement can contribute to the efficacy of private enforcement. (And vice versa.)

In Sections 3 and 4 we introduce measures of public enforcement based on regulatory budgets and staffing levels of securities market regulators, and then describe the data and present our findings. First, we explore the relationship between our new measures of public enforcement and the size of a country's capital markets. Allocating more resources to public enforcement is positively associated with robust capital markets, as measured by market capitalization, trading volume, the number of domestic firms, and the number of initial public offerings. We then control for measures of private law enforcement. Our resource-based public enforcement variables' relationship to stock market development is robust to controls for private-law legal factors, such as disclosure and liability rules, which prior findings suggest are critical to developing and maintaining strong securities markets. Public enforcement often dominates liability standards, a result consistent with current legal thinking that private securities litigation, at least in the United States, is poorly designed. In horse races between our resource-based measures of public enforcement and formal measures of public enforcement powers used in prior academic work on the subject, our new measures of public enforcement are more strongly associated with robust financial markets. Moreover, the two previously used prominent formal measures of public enforcement do not correlate with one another, further suggesting that indexing formal regulatory powers may not be the best way to measure real public enforcement intensity and that real resources may well be the better proxy. 
The data here do not, however, have public enforcement uniformly trumping private enforcement. First, the results soften when we account for influential observations, although when we do so, public enforcement persists as being as, or more, significant than private enforcement. While the liability standards variable associated with private litigation proves to be largely insignificant, the disclosure variable is often significant. In some areas, public enforcement may be less effective than private enforcement; in others the opposite may be true. As an example of the former, our public enforcement variables do not predict country-by-country results of variables associated with highly dispersed ownership of public firms. As examples of the latter, our measures of public enforcement are more highly correlated with a country's stock market capitalization and its ratio of domestic firms to population.

We also discuss causality. Maybe more public enforcement produces better outcomes; maybe stronger financial outcomes call forth higher budgets and deeper staffing. In particular, widespread ownership of financial assets in a democracy should make it easier for government officials to spend resources on public enforcement. If influential elements of the polity own financial assets, they will insist on being protected from insiders' machinations. Unpacking causation is complicated, however, as data limits preclude differences-in-differences and country fixed effects regressions, and the alternative of finding a suitable instrument has vexed academic finance for a decade. We see the two aspects - market results and budgets - as likely to be simultaneously determined, with financial results and private enforcement likely to be similarly simultaneous as well, with causation for both relationships bidirectional.

A widely held view in academic finance is that investor protection is vital for financial markets to develop. For those who hold that prior, which we share, identifying the channels for investor protection is important. Prior work rejected the importance of public enforcement, because the public measure usedthe regulators' formal authority — did not correlate strongly with financial market outcomes. These results induced some influential policymakers to reject public enforcement. Because our resource-based measures of public enforcement correlate significantly with financial market outcomes, the best evidence 
does not warrant rejecting public (or private) enforcement as vital for investor protection in supporting financial markets.

In Section 5, we discuss the channels through which public enforcement could improve financial markets and offer cautionary notes for policymakers. Public enforcement strength can indicate the degree to which the public authority can (1) conduct market surveillance, by addressing general systemic issues and problems that need rule-making fixes, (2) investigate individual firms for wrongdoing, (3) bring enforcement actions (including those that result in large financial penalties or criminal imprisonment), and (4) write, revise, and enforce better, more sophisticated regulatory rules. We cannot distinguish which among these four channels for public enforcement is the most important.

Moreover, public enforcement has multiple targets. Much analysis focuses on corporategovernance-related enforcement, especially that connected with tunneling value out from the firm into controllers' hands. Tunneling and related party transactions are important and deserve the attention they have received. But deep public markets also require brokers and other securities-handling institutions that are often intensively regulated in the United States and other countries with deep capital markets. Trading channels have not been the focus of analysis in the law and finance writing of the past decade, yet reliable trading channels might be critically important to building a strong securities market.

La Porta et al. (2006) and Djankov et al. (2008) are the works closest to ours, although they conclude that public enforcement is of limited value and we conclude otherwise. Key policy analysts quickly accepted the relative value of private over public enforcement, with the World Bank advising "[i]n banking and securities markets, characteristics related to private monitoring and enforcement drive development more than public enforcement measures": World Bank, 2006b, p. 1. See also World Bank, 2006a, p. 39-44. Researchers currently with the International Monetary Fund (IMF) and the European Central Bank conclude similarly (Bruno and Claessens, 2008; Hartmann et al., 2007). Policymakers with such views would promote private enforcement rules and institutions to the detriment of public enforcement institutions. Our analysis indicates this to be a policy error. To the extent that securities law 
enforcement matters to financial markets' breadth and depth, the resource-based evidence here is inconsistent with private enforcement being superior to public enforcement.

\section{Public and private enforcement in prior legal analysis}

At the outset we were skeptical of a claimed superiority of private enforcement over public enforcement. Prior financial analyses' faith in private litigation seemed misplaced, as the conventional legal academic view, which we share, is that securities litigation, at least as practiced within the United States, is seriously compromised. Private securities lawsuits in the United States (1) often provide meager returns to wronged plaintiffs, (2) usually do not visit their costs on the wrongdoing actors inside public firms, because the wrongdoers can usually transfer the costs to others, and (3) often just transfer losses from one innocent group of shareholders to another innocent group, with large fees obtained by the lawyers for both sides (Coffee, 2006; Cox et al., 2003; Grundfest, 1994; Romano, 2005). These failings of private litigation arise from familiar limits on dispersed shareholders' oversight, whether via litigating, voting, or otherwise seeking to control insider, managerial misbehavior: dispersed ownership creates collective action problems that dilute shareholders' capacity to litigate effectively, to vote efficiently, or to take other remedial actions to control insider misbehavior (Berle and Means, 1932; Jensen, 1986, 1989; Jensen and Meckling, 1976). Private securities litigation via class actions to remedy the disabling effects of shareholder dispersion often results in class action attorneys controlling the litigation in ways that do not fully benefit dispersed shareholders. Ownership dispersion weakens private enforcement. Director liability in private shareholder suits is rare (Black, Cheffins, and Klausner, 2006). And private enforcement cannot provide a wholly or even largely self-sufficient system of securities regulation, as the transactions costs of private remedies for even basic issues like insider trading stymie private enforcement from being fully effective. Litigation-based forms of private enforcement can cover only certain kinds of corporate wrongdoing. Indeed, the major securities reform statutes of the 1930 s were enacted to address these shortcomings of private enforcement (Seligman, 2003), and the Securities and Exchange Commission (SEC), a public regulator, has played a major role in American securities markets ever since. 
As a matter of casual observation, most well-developed capital markets use multiple public regulatory functions that dispersed shareholders and other private parties are poorly situated to undertake, due to the heavy transaction costs of doing so. Detecting insider trading and market manipulation in practice uses centralized oversight of trading markets, functions that neither a single shareholder nor even all the shareholders of a single corporation have yet been able to maintain efficiently. Disclosure requirements and consistent accounting rules are public goods that private parties on their own would have difficulty devising, updating, and enforcing. Periodic examinations and inspections of brokerdealers are typically the province of government or quasi-public self-regulatory agencies. Systemic risks and liquidity crises are not readily remedied by private contracts or ex post litigation, as the recent worldwide financial interventions illustrate, but are tasks for the public regulators.

Finally, private parties cannot impose critical sanctions, such as revoking licenses or imposing criminal penalties. Because detection is imperfect, the usual incentive-based thinking runs, deterrence requires that punishment exceed the private gains. A criminal penalty is one way to do that. While the problems of public administration are familiar and profound-public officials have imperfect incentives, are often poorly informed on many market matters, and are too often corrupt - the widespread use of public enforcement suggests it may still help to develop or maintain robust capital markets. Public enforcement is highly imperfect, but because private enforcement is compromised by free-rider and other weaknesses, public enforcement may still be useful.

Furthermore, central elements of private enforcement in practice depend on public enforcement. Consider the centrality of private enforcement based on price movements of securities in response to good and bad news about corporate activities (and the allocative and corporate governance actions that often result). Prompt publication of such news depends on the reliability of corporate disclosure. But in all developed capital markets, public authorities such as the SEC heavily regulate corporate disclosure and penalize egregious failures of accurate disclosure. Private measures could in theory develop reliable disclosure and policing, but do not seem to have done so, perhaps due to Coasean coordination problems and the costs of developing private reputations and sanctioning mechanisms. And, for shareholders to 
effectively exercise voting power, another key source of private enforcement, they also typically depend on publicly enforced, mandatory disclosure. Lastly, class action securities litigation in the United States usually results from the failure of corporations or their officers to comply with publicly articulated disclosure standards. Recent empirical work suggests that initiating an SEC enforcement action substantially increases the likelihood that private lawsuits will be brought (Cox et al., 2003). On many dimensions extensive public enforcement appears to be a prerequisite to effective private enforcement.

A final source of our concern with prior work here was the formal manner in which public enforcement was measured. La Porta et al. (2006) measure public enforcement intensity via the financial supervisor's formal qualities: independence from the executive, its investigative powers, its capacity to issue remedial orders, and the range of criminal sanctions available. They assign values to each of these characteristics, then add them up to build what they see to be an index of public enforcement (the LLS index). Similarly, Djankov et al. (2008, p. 435) develop a second formal index of public enforcement based on whether the regulator can sanction a specified insider transaction via "(1) [a] fine for the approving body; (2) jail sentences for the approving body; (3) fines for [principal wrongdoer]; and (4) [a] jail sentence for" the principal wrongdoer.

Indexing the regulators' formal qualities is a plausible place to begin, but it falls short of reliably indicating public enforcement's bottom-line efficacy. Familiar problems afflict developing accurate cross-country indices of legal rules, in that it's difficult to obtain consistent classifications across jurisdictions and weight multiple factors appropriately (Armour and Lele, 2008). Interpretive considerations are also in play, in that the character of key legal factors included in earlier public enforcement indices seems ambiguous and open to interpretation as to importance and even directionality. The LLS index, for example, gives more points to an independent regulator, like the American SEC, and fewer to one integrated into a consolidated financial supervisor, like the British Financial Services Authority. While regulatory specialization, such as the SEC's, may be useful, the wider regulatory vision of a consolidated regulatory operation could actually improve supervisory oversight. Prior literature is 
divided on the merits of consolidated supervision (Čihák and Podpiera, 2006). Hence, it is not clear that independence trumps consolidation, casting doubt on the theoretical value of the LLS index's coding.

A more basic problem with an authority-based enforcement index is that it relies too heavily, in our view, on the regulators' formal legal powers to investigate and sanction. Consider the power of a securities regulator to refer securities law violations to criminal justice authorities to prosecute. Many regulatory authorities that have these powers do not use them (Jackson, 2006). Research into the efficacy of insider trading regulation (Bhattacharya and Daouk, 2002) shows the key issue not to be whether the regulator has the formal power to sanction offenders, but whether it actually exercises that power.

For these reasons, we set out to better measure the intensity of public enforcement, in order to better ascertain the extent of public enforcement's relationship with robust capital markets.

\section{Data description: Measuring public enforcement via regulators' staffing and budget resources}

We develop in this article several measures of the intensity of public enforcement of securities regulation based on the regulators' budgetary resources and staffing levels. Our resource-based concept of public enforcement efficacy measures the level of public resources that a nation allocates to its financial regulators, scaled to either the nation's economic size or its population. Higher budgets and greater staffing allow the regulator to examine allegations of wrongdoing, to write its rules carefully, to conduct market surveillance and review filings, and to act more often to remedy, prevent, and punish wrongdoing. Unlike prior work, we do not factor in the regulatory agencies' formal independence from other governmental authorities or their formal authority to fine or incarcerate wrongdoers. Regulatory independence and high levels of agency authority are of little value to effective enforcement if the agency's budget is minuscule and its staffing thin. And conversely, a not-very-independent regulator with a high budget and strong staffing indicates that political and market authorities have given the agency the go-ahead to enforce financial rules. Similarly, a well-staffed and well-funded agency can, even if it has only limited formal sanctioning authority, make good use of the sanctions that it has. 
To be sure, our measures based on budgets and staffing also have their limits, both in concept and construction. Simply because budgetary authorities have allocated ample resources to the regulatory authority does not mean that the regulator deploys these resources wisely or even for the purposes for which they were appropriated. Simply because a securities regulator has ample resources does not guarantee that it utilizes them to bring enforcement actions, to write good rules, and to hire good people. Deep staffing of sinecures or crony-oriented appointees may lead to a regulator showing a high budget and high staffing levels, but result in little enforcement. Indeed, we see examples of jurisdictions maintaining relatively similar regulatory staffing levels and budgets, but imposing quite different levels of public sanctions. Jackson $(2006,2007)$ shows that the U.S. and the U.K., with similar resource levels, use those resources differently, with the U.S. using more public sanctions and the U.K. focusing on other aspects of supervision. Moreover, lean staffing and a low budget, if the regulator knows how to pick battles and impose severe penalties, can yield strong public enforcement, so that private actors calculate that the probability of being caught times the penalty imposed exceeds the private benefits sought. Thus, staffing levels and budgets may be a noisy proxy for effective public oversight of capital markets.

We considered shifting to enforcement outcomes, such as indicators of aggregate regulatory actions brought, fines levied, and conviction rates. Staffing and budget are inputs, not outputs. But we did not shift focus for practical and analytic reasons. First, output data are unavailable for many countries. Second, their interpretation would be ambiguous. Low enforcement output could result from the regulators having tremendous budgets and staffing, such that financial actors would not dare break any of the regulator's rules. Third, the mechanisms of enforcement differ across national boundaries—some, like the U.K. and Japan, rely on informal discussion and administrative guidance; others, like the U.S., bring more formal actions against wrongdoers - making variables based on publicly reported formal sanctions inaccurate measures of regulatory outputs for many jurisdictions (Jackson, 2008).

Constructing a budget and staffing data set comparable across nations is not an easy task. Many jurisdictions divide regulatory responsibility among different bodies, with some bodies operating as selfregulatory organizations and others located within subnational jurisdictions, such as states or provinces. 
Other nations consolidate capital market regulation in a single financial supervisory agency. Breaking out the budgets and staffing of securities regulators from those of larger governmental bodies can be hard.

Notwithstanding these difficulties, we extended Jackson (2007) by assembling data on budgets and staffing for three samples of nations. We describe the data in Table 1 and present it in Table 2, drawing primarily from the 2006 edition of How Countries Supervise Their Banks, Insurers and Securities Markets, which the Central Banking Publications of London compiles annually. For several countries (Canada, Japan, Jordan, and Sweden) where the Central Banking data differed from regulators' annual reports or other similar public documents, we made modest adjustments. For each sample, we compile two measures of public enforcement. The first is the size of the regulatory staff that oversees capital markets, scaled by country population; the second is the securities regulatory budget scaled by the nation's gross domestic product. Our first sample — the most basic one — consists of countries for which the How Countries Supervise source indicates the staffing level and budget associated with securities enforcement. It yields staffing estimates for 30 countries and budgets for 26 .

How Countries Supervise (Courtis, 2006, 2007) also indicates the budgets and staffing for several consolidated regulators that regulate areas of the financial services industry beyond securities issuance and trading - typically extending to banking and/or insurance; data for such regulators are not included in the first, basic sample. But for our second pair of samples, which we denominate our extended sample, we add to the basic sample those countries where there is objective information with which to allocate staffing and budgets of consolidated agencies to the securities sector, generally through personnel reports included in annual reports or other agency publications. This extended sample includes 38 staffing and 34 budget observations.

For our final pair of samples, which we call the extrapolated samples, we add to the extended samples the remaining jurisdictions for which the How Countries Supervise data include staffing or budget estimates for consolidated agencies, but for which there is no objective metric to allocate directly the staffing and budget levels for the securities division. For these nations, we extrapolated staffing and budget estimates based on the median ratio of securities staff or budgets to other areas of financial 
regulation where direct data on both levels were available. ${ }^{1}$ The extrapolated sample includes 53 staffing and 46 budget observations. We describe these and our other variables in Table 1 and report in Table 2 the values of the staffing/population and budget/GDP measures for the three samples. Sample construction here is imperfect: The extrapolated sample is the largest, but the noisiest. The extended sample is more objective, based on data (without extrapolation) from the regulator, but there may be a selection effect in which nations' regulators report objective data used for our allocations. The basic set has less noise, without the weakness of the extended sample's selection bias, but is biased toward nonconsolidated regulators and has fewer observations. Below we indicate some parameters for constructing better measures of regulatory intensity.

In the tables that follow, we emphasize results based on the extended sample. We do so because the extended sample is the largest sample based on objective, not extrapolated (and, hence, based on less noise), measures of staffing and budgets. But we also run our principal regressions with the basic and extrapolated samples and include the most important results with these alternative samples in the unpublished appendix. For all principal findings, the results are consistent across the three pairs of resource-based samples.

Countries allocate sharply differing levels of resources to financial oversight. Some differences reflect the differing roles of financial markets in certain jurisdictions: Financial centers like Hong Kong and Luxembourg have the highest staffing and budgets, and they are jurisdictions where financial activity plays a large role in the domestic economy. But even among more traditional economies, variation is ample. Canada reports nearly 39 regulators staffing their securities agency per million of population whereas Spain, with a comparable GDP, reports only slightly more than eight staffers per million of population. By this measure Spain's regulatory intensity is one-fifth that of Canada.

\footnotetext{
${ }^{1}$ As a rough check on this method of extrapolation, we examined the allocation of consolidated staff and budgets (using median ratios) in the extrapolated sample to the extended sample's consolidated regulators' allocations that were based on objective data. In roughly one-third of the cases, the allocations were close to the extrapolation ratios; in another third (for countries such as the U.K. and Luxembourg) the ratios were higher; and in the final third (countries with smaller capital markets such as Iceland and Germany), the allocations were lower. This relatively even distribution of adjustments suggests to us that our crude extrapolation technique was not obviously biased.
} 
In Table 3, we report pairwise correlation coefficients for the principal variables we use, including indices from LLS (2006) and Djankov et al. (2008) of the regulators' formal public enforcement powers. These latter indices seek to measure public enforcement intensity by building indices of law-on-thebooks of the formal powers of the public enforcers. The indices of the regulators' formal powers correlate only modestly with the resource-based measures - they are generally positive but never greater than 0.5 . Accordingly, some countries must be adopting formal rules that could facilitate enforcement, but then fail to allocate the staffing and budget that could make the regulator effective. France illustrates this phenomenon. It has a quite high formal powers index score of 0.77 on the LLS measure, more than a standard deviation above the public enforcement's mean, suggesting a strong regulator. But its regulatory budget is only $\$ 28.9$ thousand per billion of GDP, roughly one-third of the mean, suggesting a weak regulator. The French securities regulator's formal powers and independence indicate France to be high on public enforcement, but its resources indicate it should be coded as low. This helps to explain why our results for public enforcement (as predicting financial strength) differ from prior inquiries. The Netherlands, in contrast, has a slightly below average formal public enforcement authority, but if we use resources to measure public enforcement, it ranks well above the mean.

The correlation matrix in Table 3 shows the degree to which staffing and budget correlate with other indices of interest, such as three formal legal indices (a securities disclosure index, a liability index, and an anti-director rights index) and a judicial efficiency index. As would be predicted, our variables positively correlate with these other indices, in 23 of the 24 pairings. Hence, some of the good financial results previously associated with the three formal legal indices could be due to their correlation with the intensity of regulatory enforcement.

A final point on Table 3: The two leading indices of formal enforcement powers do not correlate with one another, with a negative pairwise correlation coefficient (-0.11). As we discussed above, questions afflict how to understand the value, and even directionality of, these indices' components. Their lack of correlation raises further questions about their value for statistical analysis as proxies for effective public enforcement. 


\section{Results}

Our basic research pattern is first to replicate prior analyses of public enforcement from La Porta et al. (2006), substitute our new resource-based measures of public enforcement for the prior enforcement indices, and then check for robustness, including robustness when controlling for private enforcement. The results throughout have resource-based public enforcement strongly and significantly correlating with the size of domestic capital markets. The resource-based indicators are consistently as strongly associated with robust capital markets as the best performing index of private enforcement (disclosure) and substantially more strongly associated with robust capital markets than several other indices of private enforcement, including liability rules and anti-director rights.

\subsection{Replicating La Porta et al. (2006), but with resource-based public enforcement measures}

In Table 4, we replicate and then re-examine prior work that sees public enforcement as not having much impact on financial market development (see La Porta et al., 2006), following them in first using their primary measures of capital market strength: stock market capitalization, trading volume, number of domestic firms, and the number of IPOs.

Within each panel, we run five sets of regressions for each capital markets measure. In each set, we first replicate the original LLS regression (column 1) on enforcement, then substitute our resource-based variable for the LLS formal enforcement index (columns 2 and 4), and then in each case present an additional regression with both the real resource variable and a formal public enforcement index (columns 3 and 5). In columns 2 and 3, we employ the staffing variable from our extended sample; in columns 4 and 5, we use our budget variable from the extended sample. We repeat these regressions for all four variables measuring the robustness of capital markets.

Overall, resource-based enforcement relates more strongly to capital markets outcomes (significant in 14 of 16 appearances in Table 4) than the LLS formal enforcement index (significant in only three of 12 appearances). The resource-based variables are significant in seven of the eight cases in which they appear without the formal enforcement measure. In the eight instances in Table 4 where both measures of 
public enforcement appear (columns 3 and 5), our resource-based measures are statistically significant seven of eight times; formal enforcement is significant only once. ${ }^{2}$ Resource-based enforcement dominates formal enforcement in these regressions.

Introducing resource-based public enforcement affects the formal public enforcement measures' significance. Consider Panel D of Table 4, where the dependent variable is the level of IPOs. The formal enforcement index is, when run alone, significant. When we add staffing or budget to the regression, each is significant but the coefficient for formal public enforcement index not only loses significance but also turns negative in the face of staffing.

\subsection{Public enforcement, controlling for private enforcement}

We next see, in Tables 5 and 6, whether resource-based public enforcement is robust to private enforcement. We run regressions similar to those in Table 4, but add the two private enforcement indices that in prior research were associated with robust capital markets: disclosure and liabilities standards. We use as dependent variables more current 2004 data from the World Bank databases, because we are no longer seeking to replicate the prior LLS work on formal public enforcement (which used more dated measures of capital market development), ${ }^{3}$ but seeking to test the robustness of resource-based public enforcement in the face of private enforcement, and vice versa. We use a contemporary wealth control adjusted for purchasing power parity, ${ }^{4}$ a control for judicial efficiency, and a control for corporate law with Djankov et al.'s (2008) anti-director rights index. Results are in Tables 5 and 6.

Djankov et al. (2008) and La Porta et al. (2006) show an association between disclosure and liability standards on the one hand and robust capital markets on the other. We attempt to replicate these

\footnotetext{
${ }^{2}$ In Tables 5 and 6 , we run similar tests using updated data in a more demanding fashion by adding private enforcement measures. Results for resource-based enforcement are similar to those in Table 4. We also re-ran the regressions in Tables 4, 5, and 6 to look for sampling effects. Sampling effects do not drive the results, in that the public formal enforcement index as well as measures of private enforcement generally perform similarly across samples. See Tables 4A, 4B, 5D, and 6F of the unpublished appendix.

${ }^{3}$ These dependent variables are analogous substantively to those used in La Porta et al. (2006), whose results we replicated, extended, and subjected to alternative measures in Table 4. But this data is more recent, based on 2004 data rather than averages for their 1996 to 2000 data. Because several of the underlying independent variables are now more recent measures, we used contemporary wealth controls whenever possible. Also, our domestic firms' measure is based on the ratio of domestic firms to population, not the log of that ratio. A full list of our 2004 dependent variables appears in Appendix Table 2. To confirm that our use of dependent variables from a single year did not affect results, we re-ran our key tests using dependent variables based on five year averages, 2001 to 2005 , and found similar results. See Appendix Tables $5 \mathrm{H}$ and $6 \mathrm{~J}$.
} 
findings when conditioned by resource-based public enforcement. Consider the first four columns of Panel A in Table 5, where the dependent variable is 2004 market capitalization and the independent variables include the major private law indices plus an index of formal public enforcement. Here, disclosure displays a consistently significant relationship to market capitalization. But public enforcement, measured by the index of formal powers, does not, ${ }^{5}$ nor does the liability index, which has a negative coefficient in column 4. The results in the next five columns of Panel A, however, call into question the robustness of those findings. Once we add our resource-based staffing variable in columns 7 and 9 , the coefficient for disclosure remains positive but stays significant in one of its two appearances. In columns 8 and 9 , the coefficient for the private liability index is negative, significantly so in the final column with a full set of controls. ${ }^{6}$ Yet, through all five formulations for Panel A, our resource-based public enforcement variables retain statistically significant, positive coefficients.

Results are similar in the other panels of Table 5, where we present analogous regressions for our three other measures of robust capital markets: trading, domestic firms, and IPOs. In 19 of 20 cases in Table 5, the staffing variable has statistically significant coefficients. While the disclosure index is often enough significant when run with staffing resources, it overall performs more erratically, especially in Panels C and D, where its coefficient turns negative in the face of the staffing variable. The liability index is rarely statistically significant in the face of staffing and regularly turns negative, sometimes significantly so. Fig. 1 illustrates the staffing results for the four panels.

The results in Table 5 are consistent with the many alternative formulations we discuss below and note in the appendix: both our real resources variables and the LLS disclosure index are generally associated with robust capital markets. Our public enforcement variables do better than the disclosure

\footnotetext{
${ }^{4}$ Although $\log$ GDP/capita is common, purchasing parity indices have been used to more accurately show wealth contrasts. The choice of wealth controls does not affect results.

${ }^{5}$ La Porta et al. (2006, p. 25) indicate that "the (log of) the number of employees is insignificant" but do not report their results. Their verbal description does not indicate that they scaled each nation's staffing variable.

${ }^{6}$ Disclosure though is significantly associated with other financial outcomes, an overall result consistent with our priors on the importance of disclosure, which is often enforced through public means. But in contrast, results for liability rules do not support their importance. Liability rules may affect litigation outcomes without affecting securities markets' depth. To check whether anti-director rights and disclosure were themselves affecting the liability coefficient, we re-ran the regressions without them, with just liability against resources. As we report in Table 13A of the appendix, liability continued to do as badly, while the resource-based public enforcement measures were always significant.
} 
index in predicting the dependent variables measuring the ratio of domestic firms to population (Panel C) and IPO value to GDP (Panel D), with the coefficient for disclosure turning negative in the face of staffing in both panels. The disclosure index and our real resource variables have comparable levels of association with market capitalization to GDP (Panel A). The disclosure index, in contrast, is more strongly significant in predicting trading levels (Panel B), although both are typically significant.

In Table 6, we run analogous regressions using the regulator's budget (as a proportion of the country's GDP) to measure public enforcement. The results, illustrated in Fig. 2, are quite similar: resource-based public enforcement is always significant; the results for private enforcement are mixed, with disclosure insignificant in four of the eight relevant runs (turning negative once) and liability only significant once, but then with a negative sign.

The resource-based results are significant economically as well as statistically. The average ratio of stock market capitalization to GDP in the extended sample is about $80 \%$. The coefficient for our budget variable (0.73) in Panel A of Table 6 implies that an increase of one standard deviation in the level of an average country's budget (\$108.6 thousand) would be associated with nearly doubling an average nation's stock market capitalization. The implied impact of an increase of one standard deviation in the securities disclosure index would be to increase an average country's market capitalization to GDP by less than $20 \%$.

\subsection{Robustness checks and tests with alternative samples}

These results are consistent with public enforcement playing a role in keeping financial markets strong. We next examine whether these results hold up when we use the basic and extrapolated samples. The results are robust, with the basic sample's resource-based variable doing better than the extended sample's, and the extrapolated sample's doing somewhat worse.

\subsubsection{The basic and extrapolated samples}

For the basic staffing sample of 30 observations, the data set typically has sufficient data for the other variables for 27 or 28 observations to be present in three panels, but only 20 in the fourth, due to 
limitations in the number of observations for IPO values to GDP. As before, we run the public enforcement as an independent variable in four panels, each with one of the four indicators of financial market strength as the dependent variable. Each panel again has five specifications: first, resource-based enforcement alone (with just the controls), then with formal public enforcement, with disclosure, with liability, and lastly against both disclosure and liability. The basic staffing variable is significant in all 20 specifications. Disclosure is significant in only two of the eight specifications in which it appeared. Liability did poorly: always negative, significantly so in five of the eight specifications in which it appeared. These results are presented in the unpublished appendix, in Table 5A.

For the extrapolated staffing sample of 53 observations, 44 to 46 are present in three panels, 35 in one. Extrapolated staffing, conceptually the noisiest of our samples, is significant in 15 of the 20 models. Disclosure is significant in four of the eight specifications in which it appears, but turns negative twice. Liability has a negative coefficient half the time, with the negative coefficient twice being statistically significant. Results are in Table 5B of the appendix.

For the basic budget sample of 26 observations, 24 are present in three panels, but only 17 in one. Budget is significant in all 20 specifications; disclosure in five of its eight appearances. Liability turns negative in three of its eight appearances, significantly so twice. These results are in Appendix Table 6A. ${ }^{7}$

Lastly on this robustness check, we re-ran our regressions on the extrapolated budget sample of 46 observations. In three of the four panels for outcomes, 39 observations survived, 30 in the fourth panel. The extrapolated budget variable is significant in all 20 specifications. Disclosure is significant in four of eight appearances, turning negative twice. Liability is again erratic, turning negative in three of its eight appearances, significantly so once. These results are in Appendix Table 6B.

Overall, the resource-based measures of public enforcement are robustly associated with financial market size and depth across three samples for each of two resource measures.

\footnotetext{
${ }^{7}$ We also normalized the extended budget variable by population (instead of GDP), because three of the four primary outcomes had GDP denominators. The results, reported in Appendix Table 6D, were similar, with extended budget variable significant in all of its 20 appearances.
} 


\subsubsection{Influential observations}

With the relevant samples no larger than 53 observations, we examined the potential impact of influential observations. Hong Kong, Luxembourg, and Singapore have deep and broad financial markets and devote significant resources to supporting their markets. At one level, these observations are consistent with resource-based public enforcement playing a key role in financial markets. Hong Kong, for example, is reputed to be one of the toughest public securities regulators, one that regularly applies tests of substantive suitability (a standard stronger than that of adequate disclosure). And, while the figures show Hong Kong as an influential point, a visual relationship persists in Figs. 1 and 2 between the other nations' financial outcomes and enforcement resources. To more formally test whether their influence drives the results, we first re-ran the extended sample results using STATA's robust regression (rreg), which systematically clips or eliminates outliers.

The robust regression results for the extended staffing sample are in Table 5C of the appendix. The extended staffing variable is significant in eight of the 20 specifications but turns negative in several the specifications that have trading volume as the outcome. Disclosure is significant in six of its eight appearances. Liability again is erratic, with a negative coefficient in four of its eight appearances. For the extended budget sample, the rreg results (in Appendix Table 6C) are robust, with the budget measure significant in 11 of 20 appearances. Winsorizing (at 0.1 ) yields similar results, with the coefficient on extended budget significant in 19 of our standard 20 runs (Appendix Table 6E).

We also winsorized the relevant variables and ran rreg with the basic and extrapolated samples, as Table 7 shows. There, we summarize first the distribution of coefficients for the full models in Tables 5 and 6 and then report summaries of the coefficient qualities for two variations that deal with outliers. 8 As Table 7 shows, winsorizing and robust regressions (with STATA's rreg command) reduce the frequency of significant outcomes for resource-based public enforcement, but these coefficients remain significant in $71 \%$ of the winsorized regressions and $50 \%$ of the rreg regressions. The runs include all six of the

\footnotetext{
${ }^{8}$ Table 7 reports the distribution of coefficients from a series of regressions using the full functional form of column (9) of Table 5 for regressions using staffing variables and column (5) of Table 6 for budget variables.
} 
extended, basic, and extrapolated budget and staffing samples. Often the reduction of statistical power falls only modestly below the 0.10 level for $\mathrm{p}$-values. Disclosure does not suffer from a similar decline, but for the winsorized regressions, the coefficient of the disclosure is usually positive and significant (54\%) but less so than the coefficient on the real-resource public enforcement measures $(71 \%$ positive and significant). For the rreg runs, however, the disclosure index (at 63\%) does better than real-resource coefficients (at 50\%). Liability, the other private enforcement variable, again performs erratically. Overall, both resource-based public enforcement variables and disclosure-based private enforcement do well; the private enforcement liability variable does poorly.

As a further robust check, we ran Cook's D to detect influential observations and outliers. The test often identified Hong Kong and Nigeria as influential observations. Conventional econometric technique is to examine these observations for accuracy, to consider eliminating them if inaccurate, and to check for robustness with a test such as STATA's rreg command or a similar clipping technique, such as winsorizing, to preserve the basic information but dampen its impact (Belsley, Kuh, and Welsch, 1980, p. 3; Hogg, 1979, p. 114; Kennedy, 1998). The Hong Kong observation seems accurate and consistent with reports from international securities lawyers we consulted who report Hong Kong as having one of the world's most intense securities regulators.

The Nigerian observation, though, looks suspect. Its budget/GDP ratio is four times larger than that of the U.S. and an order of magnitude greater than countries with similar wealth. A persistently misplaced decimal point is not impossible. The observation could reflect corruption or widespread sinecures.

To test the potential impact of these outliers, we reran our results in three different ways, first temporarily dropping Nigeria, second temporarily dropping both Nigeria and Hong Kong. Summaries of these two runs appear in Appendix Tables 7A and 7B. With the temporary removal of Nigeria, resourcebased enforcement's significance approaches $100 \%$, the frequency of disclosure's significance declines somewhat (to 42\%), and liability is never significant. Without either Nigeria or Hong Kong, the distribution of real-resource and disclosure coefficients are roughly comparable to one another and liability again does poorly. 


\subsubsection{Potential scale effects}

To explore the possibility of scale economies, we also re-ran our full model (column 9 of Table 5 and column 5 of Table 6) along with a control equal to the resource value, squared, divided by GDP or population. The results confirm the close association of resource-based public enforcement with financial market outcomes: the squared term was significant in nearly half of the formulations, often with a very small negative coefficient, indicating decreasing returns to scale in some models, and the significance of the linear term strengthened. ${ }^{9}$

\subsection{Financial variables associated with dispersed ownership}

So far, we have analyzed dependent variables associated with the size of a country's capital markets: stock market capitalization, turnover, number of domestic firms, and IPOs. All of these are consistent with an important role for public enforcement, as measured by the real resources of staffing and budgets. Other outcome variables measure financial depth and we turn to those now, focusing on three dependent variables closely related to the dispersion of ownership: an index measuring ease of access to public markets, median block premiums, and ownership concentration.

Some analysts have seen dispersed ownership (and low ownership concentration) as closely linked with strong capital markets (La Porta et al., 2006). Hence, they measure capital markets' robustness by the degree of dispersion (and the limited level of ownership concentration). This perspective is contested in the legal literature and some of the financial literature, because concentrated ownership can reduce managerial agency problems and, when potential agency costs are systematically high, one should expect to see more concentrated owners, even if enforcement is effective. See, e.g., Jensen $(1986,1989)$, Gilson (2006), and Roe (2002). (Since the correlation between block premiums and ownership concentration is only about 0.5 , the data are consistent with some nations having low block premiums but modest

\footnotetext{
${ }^{9}$ Results for the basic, extended, and extrapolated samples are in Appendix Tables 5G and 6I. Where the coefficient on the squared term was negative, the net effect of adding resources was still positive and almost always increasing over the range of actual observations, due to the large positive effect of the linear term. As a further test, we collapsed staffing/population and budget/GDP into a single variable, as suggested by a referee, via principal components analysis, and re-ran Table 6 . The significance of the coefficient on the single resource-based variable strengthened overall, as Table $6 \mathrm{H}$ in the appendix reports, further confirming the basic results.
} 
separation; where premiums are low, concentration may persist not because of corporate law infirmities, but because shareholders use a tool to reduce managerial agency costs.)

In Table 8, we regress these three variables associated with dispersed ownership on our two key measures of public enforcement and several other legal indices and controls. Resource-based public enforcement does not significantly predict variables associated with dispersed ownership; disclosure does. While these results require further study, at a minimum, one might conclude that to the extent that public enforcement positively influences the size of a country's capital markets, it does not directly disperse share ownership. Countries that dedicate more resources to securities enforcement do not necessarily have fewer closely held firms or lower premiums for control, although they have larger stock markets, more IPOs, and more firms overall.

Several possibilities may be in play here: One is that some nations with substantial concentrated ownership need more public enforcement resources to better control insider behavior, thereby generating a negative relationship between regulatory intensity and dispersed ownership. Corporate law considerations for dealing with controlling shareholders differ from corporate law considerations for dealing with managerial agency costs. Bebchuk and Hamdani (2009) and Roe (2002) discuss this. Another is that public enforcement is most efficacious in dealing with the institutions of securities trading-brokers and dealers - and less effective than private remedies in dealing with corporate governance issues. Another is that the method of aggregating ownership concentration in country averages is econometrically incorrect; Holderness (2008) criticizes currently prevailing aggregation methods.

\subsection{Limits to both private and public enforcement: intermediate financial variables}

We also ran these regressions using as dependent variables the World Bank (2006c) measures of capital market development, involving the size of equity markets, ease of access to equity markets, stock market efficiency, and stock market stability. The World Bank data also have an aggregate index that includes all information about a country's capital markets. We report the regression results in Table 9. In 
each regression, we included key enforcement variables, the private-remedy-oriented disclosure index, and a wealth control. The results are largely consistent with our previous findings.

For the World Bank's aggregate equity index and the market size index, both the staffing and budget variables, as well as the disclosure index, typically have positive and statistically significant coefficients. So, as we report above, it seems that both public enforcement and disclosure are associated with more robust capital markets. For the equity market access index-reflecting the ease with which companies can raise capital - the disclosure index has a positive and statistically significant coefficient, but our enforcement variables do not. Yet neither the public nor the private enforcement variables correlate closely with market efficiency and stability, as we report in columns (7)-(10). ${ }^{10}$

Since the regressions overall show both public enforcement and disclosure to be associated with the size of a nation's capital market, one might expect that either or both would correlate with improved technical performance of the securities markets. Perhaps a better-tuned public enforcement variable would yield different results. Yet the private enforcement variables fail to predict market efficiency and stability any better. The fact that neither enforcement variable does well here is another reason to be cautious in rejecting public for private enforcement in policymaking.

\subsection{Legal origin and regulatory intensity}

The relationship between legal origin and robust securities markets has been prominent in recent scholarship. See, e.g., La Porta et al. (1998) and Roe (2006). As Jackson (2007) and Roe (2006) both observe, the level of public resources devoted to financial regulation is often higher in common law than in civil law countries, although only weakly so. This phenomenon is surprising in that the stereotypical view of civil law countries is that they regulate their economies more heavily. Segal and Whinston (2006, p. 1) explain:

\footnotetext{
${ }^{10}$ As an aside, we found no strong relationships between components of these World Bank efficiency indices, such as trading costs or price synchronicity, and either private or public enforcement. Nor did we find strong effects on national costs of capital for either our public enforcement variables or the private legal indices. Other work on this subject found several of the LLS legal indices, including their public enforcement index (of formal powers), to be associated with lower capital costs (Hail and Leuz, 2006). Other research found a relationship between some of the LLS legal indices and lower trading costs (Eleswarapu and Venkataraman, 2006).
} 
There are two basic approaches to deterring socially harmful behavior: with the threat of litigation by private parties or with enforcement by public agencies. Both approaches are used in most countries, but in varying degrees. Private litigation is common in the United States and (to a lesser extent) the United Kingdom and other "common law" jurisdictions. In contrast, the "civil law" countries, such as those of continental Europe, have far less private litigation, and rely more on enforcement by public agencies.

For financial market regulation and liability, the opposite occurs for public enforcement. Resourcebased enforcement intensity divides roughly along common law/non-common law grounds, often enough significantly so, as Appendix Table 10 indicates. Common law jurisdictions expend more effort on, and devote more resources to, public enforcement and securities regulation, challenging traditional assumptions about the primacy of public, state power in civil law jurisdictions. Hence, key institutions that seem to support financial markets are regulatory institutions, not those traditionally associated with common law's strengths, such as private liability, low governmental activity, fiduciary duties, and common-law judging.

In Table 10, we explore whether common law also positively correlates with robust capital markets once one controls for both real resources and the standard private law indices. We re-ran our principal regressions with full controls (column 9 in Table 5 for staffing and column 5 in Table 6 for budget), using our four key dependent variables with both staffing and budget variables from our three samples, yielding 24 separate regressions. We summarize the coefficients on common law for these 24 regressions in Table 10: common law is never positive and significant, and its coefficient is more often negative than positive, sometimes significantly so. The significance of the coefficients on resource-based public enforcement was frequent and that on disclosure was significant half of the time, approximately as in the prior specifications.

These results may well have policy implications. Consider a country whose policymakers seek securities market development, having otherwise concluded that enforcement supports financial markets. Table 10 thus suggests that such a country can reach toward its goal by adopting effective disclosurebased and real-resource public enforcement regimes that support capital markets. Public and private enforcement, strategies traditionally associated respectively with civil-law-style mechanisms on the one hand and common-law-style mechanisms on the other, are both associated with strong financial market 
outcomes. Once one controls for a limited number of plausible legal mechanisms to reduce corporate and financial wrongdoing, the relationship between common law origins and capital market development fades away. This resonates with recent analysis in the legal literature, to the effect that the set of basic corporate problems is small, as is the number of institutional solutions (Kraakman et al., 2004).

\subsection{The direction of causality?}

As is usual in finance, we cannot reject the possibility of reverse or bidirectional causality. In fact, our prior here is that causation is bidirectional, with strong financial markets inducing governments to protect a key constituency and a vital market sector. Strong financial markets may emerge for reasons exogenous to the intensity of public enforcement (such as economic conditions or the absence of strong alternative financial channels) and then the relevant players (such as founders, investors, and public servants) call forth strong budgeting and more staffing in financial market regulators to protect these already developing financial markets with stronger regulators. ${ }^{11}$ Prior work on enforcement rejected the public channel as causal, because the researchers interpreted their data as showing an insufficiently persistent correlation between public enforcement and financial market development. Our work shows the two to correlate, putting the causation issue back on the table for policymaking and academic research.

The finance literature in the past decade relied on legal origin as an instrument to demonstrate causality as running primarily from a legal variable to the financial outcome. The theory was that legal origin, having preceded current financial outcomes by centuries, could not have resulted from current financial markets. With legal origin often correlating with the legal variable being studied, especially

\footnotetext{
${ }^{11}$ One reader analogized the securities regulation causation issue to motor vehicle regulation: clerks at motor vehicle bureaus, like securities regulators around the world, take registration papers and charge fees. As more people drive, more fees come in and the bureaus hire more clerks, but hiring clerks does not cause more driving. There's just a mechanical relationship, running from market size to the regulator's budget and staffing. The analogy is interesting, but defective. First, funding sources differ sharply across jurisdictions (registration fees in some, levies on regulated institutions in others, and appropriations in still others), negating a primarily mechanical relationship between budget and market size. Regulators' overall budgets are typically determined by a political body. In the U.S., appropriations are not tied to fees, and the two can move in differing directions. SEC, FY 2008 Congressional Justification (Feb. 2008) (http://www.sec.gov/about/secpar2007.shtml).

Second, the analogy's causation concept is that the clerks do not cause more driving; reverse causation dominates, because the clerks only provide a license plate, check for drivers' traffic violation history, and confirm an insurance policy. But if cars lacked license plates, if theft were rampant, and if other drivers lacked insurance and drivers' licenses, with the only remedy for wrongdoing being private enforcement via a lawsuit against the thief or the driver who caused an accident, driving might well diminish, as many wrongdoers could not be found (no license plates on cars; no drivers' licenses for drivers) and cannot pay (no insurance policy). Reverse causation does not dominate even in the analogy; bidirectional causation is a priori conceptually still in play. Third, private enforcement
} 
variables relating to private litigation, the relationship makes legal origins a potentially useful instrumental variable, either formally (La Porta et al., 1998) or informally (Djankov et al., 2008). Since the theory was that private enforcement mechanisms associated directly with the common law (such as fiduciary duties) or indirectly with it were driving financial results, there was some plausibility to using legal origin as an instrument.

But problems afflict using legal origin as an instrument to anchor causality here. While staffing and budget roughly correlate with legal origin, the causal connection between common law origin and high government spending or more regulatory staffing is more obscure than for other legal-financial connections based on, say, common law fiduciary duties. The causality of corporate law's effects on finance through fiduciary duties could be plausibly tied to legal origin, because common law systems traditionally used fiduciary duties and civil law systems are thought not to use anything similar. Causality from heavy-regulation regimes to poor financial outcomes could be tied to legal origin, because civil law systems are frequently seen to regulate their economies more extensively than do common law systems. But it's the common law systems that budget more for regulation and hire more regulators, making the legal origin nexus faint.

While it's possible that the underlying idea is that common law systems just prefer financial markets, this is too attenuated to anchor it as an instrument. After all, we are no longer talking of institutions-like fiduciary duties, judicial enforcement, and a common law aversion to regulatory intensity_-but broad, overarching preferences. Financial market preferences, though, tie only weakly to origin, since origins originated long before financial markets were well developed and many intervening events surely affected preferences. Perhaps because of such concerns, even proponents of using legal origin as an instrument seem to have withdrawn their support here (Djankov, Hart, McLeish, and Shleifer, 2008a).

has the same endogeneity difficulty. The stock of securities law's disclosure rules depends in part on the depth of the securities market, the range of issuers requiring disclosure detail, and the legal system's ongoing experience with and reaction to disclosure failures. 
Nevertheless, because of legal origins' prominence in the finance literature and prior readers' comments, we first ran two-stage least squares regressions using legal origins as an instrument, using the full model of the forms of column 9 in Table 5 and column 5 in Table 6. Neither public nor private enforcement indices such as disclosure are effectively instrumented by common law in Appendix Table 12A. The coefficients on the outcome variables of interest—financial market depth and breadth-were never significant and often negative. This lack of significance, and the frequency of the unexpected sign, occurs for both of the resource-based public, and the disclosure- and liability-based private, enforcement measures when instrumented by origin.

We investigated a second instrument: the log of GDP. There are economies of scale in the regulatory staffing and regulatory budgets. This phenomenon is reflected in a consistently negative correlation between the logarithm of national GDP and resource-based public enforcement and makes it a potential instrument to explore causality. Scale effects appear to exist for some private enforcement indices, such as the LLS disclosure index utilized in many of our previously reported regressions: the larger a country, the more extensive its disclosure requirements; hence, log of GDP is a plausible instrument for private enforcement as well. The prime conceptual difficulty is that larger economies may need even larger securities markets, leading to some causation leakage from the enforcement channel.

We report the results from using this instrument in Table 12B of the unpublished appendix. While one must be careful about making strong inferences from analyses of the sort presented in the appendix (see Murray, 2006), the results are suggestive, in that the coefficients associated with resource-based enforcement are statistically significant in six of eight cases. But, in addition to the direct instrument-tooutcome causation problem, their strength is tempered by the number of regressions that have CraggDonald $F$-statistics beneath the relevant Stock-Yogo critical values, suggesting a weak instrument.

Still, the log of GDP instrument is not a strong instrument, and hence the evidence is only suggestive. However, the results are no worse than those found using similar instrumental variable analysis offered for a causal link between private enforcement and robust capital markets. More anecdotally, regulatory budgets rise after market problems - scandals and crashes — and shrink during 
market highs. The American experience in the 1990s illustrates: When the stock market did well, Congress cut the SEC's funding. After the Enron scandals broke, Congress raised the budget and expanded the SEC's staffing. Increased public enforcement resources did not follow the market's rise, but followed its weaknesses. We understand this to be a familiar pattern around the world. Moreover, the securities markets that have been most successful in attracting new listings in recent decades - the United Kingdom, Hong Kong, Luxembourg, and, until recently, the United States-dedicate high levels of resources to securities enforcement. Dharmapala and Khanna (2008) compare Tobin's Q in two samples of similar firms in India, with the first subject to tougher corporate governance rules with serious public enforcement sanctions and the other not subject to new rules. Q for the first group had a significantly greater increase than for the second. Recall that our argument here is that academic writers and policymakers should not yet dismiss public enforcement as a potentially central source of capital market development. The regular correlation indicates that it cannot yet be dismissed, even if causality cannot yet be decisively shown.

Endogeneity analysis for World Bank-type policy differs from academic analysis. As long as causation is bidirectional (and not solely reverse causation), policymakers should not sharply reject better public enforcement to build up markets. Moreover, showing causality here is less compellingly necessary today analytically than it would have been a decade ago. A view has emerged that corporate and securities laws, and their enforcement, are vital for strong financial markets (La Porta et al., 1998; Bebchuk, 1999). For those with this prior belief, a core issue is to uncover which enforcement channels are in play. The cross-section analysis here puts public enforcement regularly and significantly in play.

\section{Discussion}

Here we discuss why prior research led to contrasting conclusions and what consequences follow.

\subsection{The importance of public enforcement}

Although our method is in the spirit of the cross-country legal methodology that La Porta et al. (1998) pioneered in finance, the public enforcement results we report above and the inferences we make 
differ sharply from La Porta et al.'s (2006, pp. 7-9), who report the following principal findings:

Perhaps most interestingly, both disclosure requirements and liability standards are positively correlated with larger stock markets. ...

The results for public enforcement ... are less consistent. Public enforcement only matters for the external-market-capitalization-to-GDP ratio and IPOs, although it has a large economic effect on both variables. ... In contrast, anti-director rights, but not public enforcement, matter for the number of firms, block premium, and ownership concentration.

These results suggest a preliminary view of what works, and what does not, in securities laws. Public enforcement plays a modest role at best in the development of stock markets. In contrast, the development of stock markets is strongly associated with extensive disclosure requirements and a relatively low burden of proof on investors seeking to recover damages resulting from omissions of material information from the prospectus. La Porta et al. (2006, pp. 19-20, emphasis supplied).

The authors conclude: "All the evidence," they state, "suggests that relying on public enforcement is unlikely to be a useful strategy for jump-starting the development of securities markets in poor countries.” Id. at 25 (emphasis supplied). ${ }^{12}$

The results here with resource-based measures of public enforcement differ. The private enforcement liability standards are regularly insignificant and regularly with the sign reversed (sometimes significantly so). Resource-based public enforcement is regularly associated with deeper securities markets, as strongly as is disclosure. There's no significant evidence here that liability standards play a role in developing financial markets. And public enforcement appears to have a strong and significant association with securities markets, suggesting that it could well play a role in developing securities markets in poor countries. When measured in terms of resources, public enforcement has a consistent and robust association with four key dependent variables that measure robust external capital markets. The results persist across three different samples and using both staff as a percentage of population and budget as a percent of GDP as measures of public enforcement.

\subsection{Channels from public enforcement to financial outcomes}

\footnotetext{
${ }^{12}$ Their reference to "all the evidence" is puzzling as some of their results show even the formal-powers-based public enforcement to be associated with both external-market-capitalization-to-GDP ratio and IPOs, with public enforcement having "a large economic effect on both variables" ( La Porta et al.., 2006, p. 2). Glaeser, Johnson, and Shleifer (2001) concluded earlier that Czech hands-off regulation in the 1990s failed while the Polish "strict enforcement of securities law by a highly motivated regulator was associated with a rapidly developing stock market." That conclusion is consistent with our results; the hands-off, no-public-enforcement conclusion is not.
} 
While our results show that public enforcement is clearly associated with important financial market outcomes, we are less sure of how it is associated and, to the extent it plays a causative role, how it does so, because it can affect financial markets through several channels. First, high budgets and staffing make it easier for the public authorities to conduct market surveillance by looking for wrongdoing and problems that need rule-making fixes. Market actors should see authorities as more likely to detect deviant and punishable transgressions in nations where budgets and regulatory staffing are higher. Second, once wrongdoing is detected, more resources facilitate regulatory investigations, making it easier for the agency to bring enforcement actions, including those that result in large financial penalties and even jail terms. The penalties for these enforcement actions are also the indirect ones from public enforcement damaging the firm's organizational and reputational capital. The reputational damage is quite high, as trading partners impose market penalties that often exceed the direct financial penalties, at least in the United States (Alexander, 1999; Karpoff et al., 2008a, b). Third, a higher budget and more staffing facilitate the regulatory agency being able to write, revise, and enforce better, more sophisticated regulatory rules. The completeness of legal rules has been shown to affect the efficacy of regulation of insider trading (Beny, 2005) and could be important more broadly. Fourth, much public enforcement is done informally, through administrative guidance in Japan or a regulator's raised eyebrow in England. Britain, with an important securities market, relies little on private litigation (Armour, Black, Cheffins, and Nolan, 2007), and much on informal public enforcement. Even self-enforcement, such as Britain's well-known City Code on takeovers, comes from a public-private panel that includes representatives from the Bank of England and the stock exchange, as well as private players, and was for years convened by, and physically met in, the Bank of England (Armour and Skeel, 2007). Such informal public enforcement requires highly skilled staffers.

Several market channels could also link public enforcement to stronger capital markets. One is the policing of the wrongdoing-potential of traditional, insider corporate governance actors who take value from outside investors unless the enforcement machinery stops them. A second is that financial markets also depend on relatively low-cost, transparent trading mechanisms. Regulatory budgets and staffing 
could make trading less dangerous for the typical shareholder, thereby deepening financial markets. Again, budget and staffing aggregates do not distinguish which market channel is most sensitive to budgets and staffing. The fact that public enforcement is closely associated with the size of capital markets, but not with the core corporate governance features that support capital markets, is suggestive that this - trading regulation as opposed to just corporate governance-may well be an important and under-appreciated enforcement channel. However, as the analysis here did not establish a consistent association between regulatory resources and technical measures of market performance, public enforcement's role in enhancing trading channels is a theoretical possibility lacking empirical validation.

Finally, the precision of regulation may relate to our measure of public enforcement intensity. When we see simple, bright-line rules in a nation, we could attribute this result to several causes. A popular one recently has been legal origin, with civil law nations using ex ante bright-line rules and common law nations using more subtle, fiduciary-based ex post decision-making. But the difference can be explained otherwise, in that simple, bright-line rules are the kind that financial regulators with a weak budget and low levels of staffing can write. If there are only a few trained people inside the regulatory agency, and the budget for rule-making is low, well-intentioned regulators may be forced to use brightline rules with sporadic enforcement. Where the budgets are stronger and the staffing deeper, the agency can write more nuanced, tailored rules.

\subsection{The significance of certain mechanisms of private enforcement; insignificance of others}

Our findings are consistent with the value of important private enforcement mechanisms (but not to the exclusion of public enforcement). Consistent with the prior findings of La Porta et al. (2006), our findings associate the quality of disclosure with strong capital markets. (But because disclosure quality depends on public enforcement's efficacy in reducing inaccuracies in private disclosure and in standardizing the disclosure and accounting across companies, it's really a hybrid of public and private enforcement.) And in some of their tests - those measuring dispersed ownership and the value of block 
premiums - private enforcement often had a statistically important association, whereas public enforcement did not.

But liability in private lawsuits does poorly in the broad range of our analysis. When run against real-resource measures of public enforcement, the liability index was often negatively correlated with robust capital markets, at times significantly. This result, while sharply in conflict with prior financial economic studies, resonates with legal academic analysis casting doubt on the efficiency of U.S. private securities litigation to police corporate misbehavior. In diffusely owned firms, innocent shareholders often effectively bear the financial burden of such lawsuits, insiders can often shift payment of any of their own liability to the corporation itself, and lawyers can often direct the lawsuits to their own advantage but not to the best advantage of shareholders and financial markets. Our results on the unimportance of liability standards fit with the fact that private securities litigation is unimportant to capital market oversight in many well-developed securities markets, such as the United Kingdom's (Armour et al., 2007). That disclosure indices are more strongly associated with robust securities markets than are liability indices suggests that private enforcement mechanisms associated with ex post litigation may not be as important as other private mechanisms such as stockholder voting and pricing accuracy. These results may thus have implications, which we do not explore here, for institutional design: The World Bank's focus on ex post private litigation, while consistent with La Porta et al. (2006) and hence with some academic support, may be over-emphasized.

We do not infer here that the intensity of public enforcement is more closely associated with strong capital markets than other factors. Rather, its intensity also predicts the size of a country's capital markets and, as Tables 5 and 6 show, the relationship between resource-based public enforcement and the size of a country's capital market is comparable to that of disclosure-based enforcement and stronger than that found for previously prominent private litigation basics, such as liability standards.

While public and private enforcement interact in important ways, they do not interact simply via higher public enforcement resources primarily going into designing better private liability systems. (Even if they did primarily interact in that way, the results here then suggest that the intensity of continuing 
public design work is what would make private enforcement effective.) A basic familiarity with the Code of Federal Regulations as it relates to securities laws reveals detailed, step-by-step instructions on what firms must do when selling securities. The bulk - more than half - of the American SEC's budget goes into basic enforcement activity. Regulators examine financial firms, review issuers' filings with the regulator, and bring enforcement actions against wrongdoers. Consider here the intensity of other, similar financial regulation. Banking and insurance industry regulatory intensity is high in nations where securities regulation is intense (Jackson, 2007, p. 271). But for both banking and insurance, even in the United States, private liability is trivial. And outside of the United States, securities regulators are rarely involved in judicial, private enforcement because there is very little of that, as Armour, Black, Cheffins, and Nolan (2007) show, so budget and staffing are likely to map onto the intensity of public not private enforcement. Bhattacharya and Daouk's (2002) result on the relationship between insider trading enforcement actions and securities markets' strength is consistent.

Overall, our results reveal a robust relationship between the intensity of public enforcement and the size of a country's capital markets. This relationship persists even when we control for legal indices measuring disclosure, liability standards, and judicial efficiency. Disclosure persists as often significant; liability standards do not. While our measures of resource-based regulatory intensity do not predict every financial outcome equally well, they predict enough of them well to support the view that public regulation plays an important role in setting the institutional foundations for securities markets.

\subsection{Corruption and enforcement}

Skepticism about public enforcement, particularly in developing nations, may be due to the wellfounded view that government officials — the market regulators themselves—often operate as a "grabbing hand" rather than a "helping hand" in the matters of economic regulation (Shleifer and Vishny, 1999). In developing nations, neither corrupt regulators who use their public power to extract bribes nor regulators in overly statist governments that use regulation to punish political opponents will build financial markets. Building up public enforcement there may just further empower deleterious elements in that 
society. Hence, analysts convinced of such a view of governmental regulatory misdirection would prefer private litigation, which they see as outside the control of government's grabbing hand.

But there is little reason to believe that private litigation via the judiciary in such nations is structurally more efficacious than public regulation: one would expect both the judiciary and the regulators to be corrupt and ineffective. For both public and private enforcement, the problem confronting nations with corrupt governments is their need to improve public administration of both regulators for public, and courts for private, enforcement. It is not obvious which institutional structure - the judiciary or the regulators - is easier to reform. Since courts deal with a broad array (contract, tort, family law, and so on), reformers may find it easier to build up specialized regulators first. The mechanisms for providing such specialized assistance-through technical assistance from agencies such as the SEC or through financial industry sponsored initiatives - are probably better developed and more effective than more broadly based assistance programs for overall judicial reforms. Regardless, as the appendix shows, adding a corruption control to our models does not weaken the resource-based results. ${ }^{13}$

\subsection{Developing better measures of public enforcement}

Finally, we note the importance of developing better measures of public enforcement. Budgets and staffing levels for a number of jurisdictions were not available and it would be preferable to gather direct information about the allocation of staffing and budgetary resources in countries with consolidated regulatory operations rather than relying on the extrapolating methods that we use. It would, moreover, be useful to collect information on the actual enforcement activities undertaken in each jurisdiction: how many cases prosecuted per year; how many sanctions imposed and with what level of monetary penalty; how many criminal convictions obtained, as the World Bank has successfully accomplished in related areas. It would also be useful to collect information on regulatory resources dedicated to other public functions, such as promulgating new regulations or conducting onsite examinations. If this paper does nothing more than to stimulate the World Bank and other agencies to develop more authoritative data, we 
will see our efforts as successful. Until then, the data do not support a conclusion that public enforcement is less valuable than private enforcement in developing financial markets.

\section{Conclusion}

The relative value of public and private enforcement is a key issue for understanding how financial markets deepen and broaden. Recent work in finance focuses on how securities laws work, concluding that private enforcement via private lawsuits among contracting parties works best. Public enforcement is seen as working poorly. Yet the legal literature has persistently found deep flaws when analyzing private enforcement mechanisms prevailing in the United States. Structural elements-like dispersed ownership - can make collective private remedies weak and put authority in the lawyers' hands, an authority that is not relentlessly used in the interest of outside investors.

Given this a priori indeterminacy, we constructed two categories of resource-based public enforcement intensity, one with regulatory budgets and another with regulatory staffing. We scaled the first to the nation's GDP and the second to its population. Public enforcement, as measured, correlated significantly with key financial outcomes, such as stock market capitalization, trading volumes, the number of domestic firms, and the number of IPOs. Moreover, in horse races between our measure of public enforcement and existing measures of private enforcement, public enforcement typically does no worse than disclosure-based private enforcement (and much better than liability-based private enforcement) in explaining these financial outcomes around the world.

Prominent academic analyses and policymaker position papers rejected public enforcement in favor of private enforcement because the former was interpreted as not correlating with deeper and wider financial markets. Without correlation, causation was not investigated for public enforcement. But because we find a strong association between outcomes and public enforcement as measured by resources, issues of causation and endogeneity, previously thought not relevant, are back in play.

\footnotetext{
${ }^{13}$ See Appendix Tables 4C, 5E, and 6G. As a further check, we re-ran our main regressions on a subsample of non-OECD countries and found similar effects for our real resource variables, although the subsample's size is smaller than we would like to have. See Appendix Tables 4D and 5F.
} 
The apparent importance of regulatory intensity goes against basic characteristics of legal origin, since common law nations do devote resources to securities market regulation, but regulatory intensity is not thought to be a characteristic tightly tied to common law institutions. Intensity's importance thus casts some doubt on the literature assessing the importance of legal origin to financial outcomes, since the tool of public enforcement (as opposed to fiduciary-oriented private litigation before judges) has not usually been strongly associated with the common law. The results are more consistent with the relevant differences in law and its enforcement being good regulation versus bad regulation rather than public versus private.

Still, there is more to do. Neither the public enforcement measures nor the private enforcement variables predict several intermediate outcomes associated with the development of strong capital markets, such as stock market efficiency or other more technical measures of stock market performance.

We emphasize that we do not see the data as telling us that public enforcement is more important than private enforcement. First, although we find, in contrast to prior work, a significant association between financial market depth and public enforcement, that finding brings back the possibility of causation, but does not demonstrate it. Causal channels have not yet been shown for either public or private enforcement. Second, some financial indicators - in particular, those associated with dispersed ownership - tie more strongly to private enforcement indices than to our public enforcement measures. Third, even where public enforcement is statistically significant, disclosure-based private indicators are often significant as well. Fourth, the measures of the intensity of both public and private enforcementand of their effectiveness - are imperfect mechanically and conceptually. Conceptually, private enforcement includes not just the measured liability considerations, but pricing and corporate voting as well. Further improving how we measure enforcement may yield a better understanding of which outcomes public enforcement most affects, which ones private enforcement influences, which channels for each are vital, and how the two main enforcement mechanisms interact. From a policy standpoint, even the persistent insignificance of the liability index may mean that the mechanisms must be improved, not scrapped. 
Overall, and most importantly, we caution against using current views of the relative value of private and public enforcement to make public policy. Public enforcement as we measure it does well in the regressions. Because public actors design both the private and public systems, the debilities of public actors can creep into both designs. The best evidence now available is that public enforcement is no less valuable for financial market outcomes than private enforcement such as disclosure and, given the weak results for private enforcement's liability measure, perhaps liability is less important. Hence, World Bank units that promote private over public enforcement are making policy without empirical backup, because the resource-based evidence is inconsistent with private enforcement being superior to public enforcement for building good securities markets.

\section{References}

Alexander, C., 1999. On the nature of the reputational penalty for corporate crime: Evidence. Journal of Law and Economics 42, 489-526.

Armour, J., Black, B., Cheffins, B., Nolan, R., 2007. Private enforcement of corporate law: An empirical comparison of the US and UK. Unpublished working paper, ECGI, Oxford University and University of Texas.

Armour, J., Skeel, D., 2007. Who writes the rules for hostile takeovers, and why?-The peculiar divergence of US and UK takeover regulation. Georgetown Law Journal 95, 1727-1794.

Armour, J., Lele, P., 2008. Law, finance, and politics: The case of India. ECGI-Law Working Paper No. 107.

Bebchuk, L., Hamdani, A., 2009, The Elusive Quest for Global Governance Standards, University of Pennsylvania Law Review, forthcoming.

Black, B., Cheffins B., Klausner, M., 2006, Outside Director Liability, Stanford Law Review 58, 1055-1059.

Belsley, D., Kuh, E., Welsch, R., 1980. Regression Diagnostics: Identifying Influential Data and Sources of Collinearity. John Wiley, Hoboken, New Jersey.

Beny, L., 2005. Do insider trading laws matter? Some preliminary comparative evidence. American Law and Economics Review 7, 144-183.

Berle, A., Means, G., 1932. The Modern Corporation and Private Property. Revised ed., 1987. Harcourt, Brace, New York.

Bhattacharya, U., Daouk, H., 2002. The world price of insider trading. Journal of Finance 57, 75-108.

Bruno, V., Claessens, S., 2008. Corporate governance and regulation: Can there be too much of a good thing? CEPR Discussion Paper No. DP6108.

Čihák, M., Podpiera, R., 2006. Is one watchdog better than three? International experience with integrated financial sector supervision. IMF Working Paper WP/06/57.

Coffee, J., 2006. Reforming the securities class action: An essay on deterrence and its implementation. Columbia Law Review 106, 1534-1586.

Courtis, N., Ed., 2006, 2007. How Countries Supervise Their Banks, Insurers, and Securities Markets. Central Banking Publications, London.

Cox, J., Thomas, R., Kiku, D., 2003. SEC enforcement heuristics: An empirical inquiry. Duke Law Journal 53, $737-$ 779.

Dharmapala, D. Khanna, V., 2008, Corporate Governance, Enforcement, and Firm Value: Evidence from India. University of Michigan, Olin Working Paper No. 08-005. 
Djankov, S., La Porta, R., Lopez-de-Silanes, F., Shleifer, A., 2008. The law and economics of self-dealing. Journal of Financial Economics, 88, 430-465.

Djankov, S., Hart, O., McLeish, C., Shleifer, A., 2008a. Debt enforcement around the world. Journal of Political Economy 116, 1105-1149.

Eleswarapu, V., Venkataraman, K., 2006. The impact of legal and political institutions on equity trading costs: A cross-country analysis. Review of Financial Studies 19, 1081-1111.

Gilson, R., 2006. Controlling shareholders and corporate governance: Complicating the comparative taxonomy. Harvard Law Review 119, 1641-1679.

Glaeser, E., Johnson, S., Shleifer, A., 2001. Coase versus the Coasians. Quarterly Journal of Economics 116, 853899.

Grundfest, J., 1994. Disimplying private rights of action under the federal securities laws: The commission's authority. Harvard Law Review 107, 961-1024.

Hail, L., Leuz, C., 2006. International differences in the cost of equity capital: Do legal institutions and securities regulation matter? Journal of Accounting Research 44, 485-531.

Hartmann, P., Heider, F., Papaioannou E., Duca, M., 2007. The role of financial markets and innovation in productivity and growth in Europe. European Central Bank Occasional Paper No. 72, available at http://ssrn.com/abstract=1005850.

Hogg, R., 1979. Statistical robustness: One view of its use in applications today. The American Statistician 33, 108115.

Holderness, C., 2008. Do differences in legal protections explain differences in ownership concentration? Working paper, Boston College.

Jackson, H., 2008. The impact of enforcement: A reflection. University of Pennsylvania Law Review Pennumbra 156, 400-411, available at http://www.pennumbra.com/responses/02-2008/Jackson.pdf.

Jackson, H., 2007. Variation in the intensity of financial regulation: Preliminary evidence and potential implications. Yale Journal on Regulation 24, 253-291.

Jackson, H., 2006. Regulatory intensity in the regulation of capital markets: A preliminary comparison of Canadian and U.S. approaches. Research Study Commissioned by the Task Force to Modernize Securities Legislation in Canada, available at http://www.tfmsl.ca/docs/V6(2)\%20Jackson.pdf.

Jensen, M., 1989. Eclipse of the public corporation. Harvard Business Review, Sept.-Oct. 61-74.

Jensen, M., 1986. Agency costs of free cash flow, corporate finance, and take-overs. American Economic Review Papers \& Proceedings 76, 323-329.

Jensen, M., Meckling, W., 1976. Theory of the firm: managerial behavior, agency costs and ownership structure. Journal of Financial Economics 3, 305-360.

Karpoff, J., Lee, D., Martin, G., 2008a. The consequences to managers for financial misrepresentation, Journal of Financial Economics 88, 193-215.

Karpoff, J., Lee, D., Martin, G., 2008b. The cost to firms of cooking the books. Journal of Financial and Quantitative Analysis 43, 581-612.

Kennedy, P., 1998. A Guide to Econometrics, Fourth ed. MIT Press, Cambridge, Mass.

Kraakman, R., Davies, P., Hansmann, H., Hertig, G., Hopt, K., Kanda, H., Rock, E., 2004. The Anatomy of Corporate Law: A Comparative and Functional Approach. Oxford University Press, Oxford.

La Porta, R., Lopez-de-Silanes, F., Shleifer, A., 2006. What works in securities laws? Journal of Finance 61, 1-32.

La Porta, R., Lopez-de-Silanes, F., Shleifer, A., Vishny, R., 1998. Law and finance. Journal of Political Economy $106,1113-1155$.

Murray, M., 2006. The bad, the weak, and the ugly: Avoiding the pitfalls of instrumental variables estimation. Working paper, Bates College..

Roe, M., 2002. Corporate law's limits. Journal of Legal Studies 31, 233-271.

Roe, M., 2006. Legal origins, politics, and modern stock markets. Harvard Law Review 120, 460-527.

Romano, R., 2005. The Sarbanes-Oxley Act and the making of quack corporate governance. Yale Law Journal 114, $1521-1611$.

Segal, I., Whinston, M., 2006. Public vs. private enforcement of antitrust law: A survey. Stanford Law and 
Economics Olin Working Paper No. 335.

Seligman, J., 2003. The Transformation of Wall Street: A History of the Securities and Exchange Commission and Modern Corporate Finance. Third ed. Aspen Publishers, New York.

Shleifer, A., Vishny R., 1999. The Grabbing Hand: Government Pathologies and Their Cures. Harvard University Press, Cambridge, Mass.

World Bank, 2006a. Doing Business in 2006: Creating Jobs. World Bank Publications, Washington, D.C.

World Bank, 2006b. Institutional foundations for financial markets, available at http://siteresources.worldbank.org /inttopaccfinser/Resources/Institutional.pdf.

World Bank, 2006c, Financial Sector Development Indices (interim data-set, described at www.fsdi.org, provided by World Bank's Doing Business Team). 
Table 1

Description of variables

This table lists our independent, dependent, and control variables. We measure public enforcement first with resources and second via the regulator's formal powers. Resources are measured by staffing levels (per million of population) and budgets (per billion US $\$$ of GDP). For each resource measure, we begin with a basic sample, as reported for 2005 by the How Countries Supervise (2006, 2007) data books. We extend each sample with staffing and budget data from other sources. We also extrapolate securities regulators' budgets and staffing for integrated regulators. We use public enforcement measures that look to the enforcement authorities' formal powers. Private enforcement variables measure the intensity of disclosure rules and measure the nature of liability in private litigation. The control variables seek to measure the countries' legal environment, their per capita wealth and income, and in some regressions, the nations' legal origin. Outcomes are standard measures of the size of securities markets, ownership considerations, and market efficiency.

Variable

Description

Sources

Public enforcement: resource-based and formal powers

Staff per million population (basic sample)

The 2005 size of the securities regulators' staff, divided by the country's population in millions.

Staff per million population (extended sample)

Staff per million population (extrapolated sample)

Budget per billion US\$ of GDP (basic sample)

Budget per billion US\$ of GDP (extended sample)

Budget per billion US $\$$ of GDP (extended and extrapolated sample)

Formal public enforcement index (LLS)

Formal public enforcement index (Djankov)

Disclosure index

Liability standards index
The 2005 size of the securities regulators' staff, divided by the country's population in millions. These data add to the basic sample of staft per million population observations for countries with consolidated financial supervisors that report some form of objective data (regarding This adds obs, staffing, or revenue sources) from which a specific proportion of total staff could be allocaled Cadal mankel oversight. observations in total.

The 2005 size of the securities regulators' staff, divided by the country's population in millions. For this variable we added tothe extended staff sample observations for countries with consolidated financial supervisory bodies that do not report separate staffing levels for securities regulators. We extrapolated securities staffing estimates by using the median ratios of securities regulator staffing to the consolidated regulator's staffing for the jurisdictions that reported enough data to construct such a ratio. This yields 53 observations.

As with the basic staff per million population, this variable is the securities regulators' 2005 budget divided by the country's GDP. The As wit reports were adjusted to US dollars at the December 31, 2005 exchange rates.

Analogous to extended staff sample, yielding 34 observations, by adding budgets for securities regulators in consolidated financia authorities for which objective allocation of the securities regulatory budget was possible. Budgets in local currency were adjusted to US dollars at the December 31, 2005 exchange rate.

Analogous to extrapolated staff sample, yielding 46 observations. We added 12 observations to the extended budget sample for nation where overall staffing of the consolidated financial agency was available. We used the median ratio of securities sa

Formal public enforcement equals the arithmetic mean of: (1) supervisor characteristics index; (2) its rule-making power index; (3) its investigative powers index; (4) orders authority index; and (5) criminal authority index, as La Porta et al. (2006) describe.

Public enforcement here is an index aggregating whether certain suspect corporate transactions can lead to a fine or jail sentences for the approving body, or fine or jail sentence for the principal wrongdoer.

\section{Private enforcement indices}

The index of disclosure equals the arithmetic mean of: (1) nature of liability on a prospectus; (2) extent compensation must be disclosed; (3) shareholders' disclosure; (4) extent inside ownership must be disclosed; (5) ex that related party and irregular transactions must be disclosed, as La Porta et al. (2006) describe.

The index of liability standards equals the arithmetic mean of: (1) liability standard for the issuer and its directors; (2) liability standard for the distributor; and (3) liability standard for the accountant, as La Porta et al. (2006) describe.
How Countries Supervise $(2006,2007)$, updated with and Jordan; including only those countries where actual staffing levels were reported. Population data downloaded from World Bank Data and Statistics Web site.

How Countries Supervise $(2006,2007)$; regulators' annual reports and similar for several nations, as listed
in the Appendix, Table 1. Population data downloaded in the Appendix, Table 1. Population data downloaded from World Bank Data and Statistics Web site. Individual country online sources are listed in the

How Countries Supervise $(2006,2007)$; regulators annual reports and similar official documents for the World Bank Data and Statistics Web site.

How Countries Supervise $(2006,2007)$, updated with regulators' annual report corrections for Canada, Japan and Jordan. GDP data downlo ded from World Bank

How Countries Supervise $(2006,2007)$; regulators' annual reports and similar oficial documents, as listed in the Appendix, Table 1. GDP data downloaded from

How Countries Supervise $(2006,2007)$; regulators' and reports and similar official documents. GDP da

La Porta et al. (2006)

Djankov et al. (2005) 
Table 1 (cont'd). Description of variables.

Anti-director rights index (original and revised)

Judicial efficiency index

Common law jurisdiction

Ln GNI per capita

Log of GDP

Market capitalization

Trading volume

Domestic firms

IPOs to GDP

Block premiums

Ownership concentration

Access to equity

Equity index

Equity Market Size Index

Equity Market Access Index

Equity Market Efficiency Index

Equity Market Stability Index

\section{Control variables} An index formed by adding one when: (1) shareholders can mail in their proxy vote; (2) shareholders are not required to deposit their
shares prior to the shareholders' meeting; (3) cumulative voting is allowed; (4) an oppressed minorities mechanism is in place; (5) shareholders have preemptive rights by default; and (6) shareholders owning or voting $10 \%$ of the share capital can call a shareholders' meeting

Assessment of the efficiency and integrity of the legal environment as it affects business, particularly foreign firms produced by the country risk rating agency International Country Risk (ICR). It may be taken to represent investors' assessment of conditions in the country

Coding of countries by legal origin, as provided by LLSV (1996). Any data missing from La Porta et al. is coded using the CIA Factbook

The log of gross national income per capita in 2005 adjusted on the basis of purchasing power parity.

The log of 2005 gross domestic product in current US dollars.

\section{Outcome variables}

Ratio of a country's 2004 stock market capitalization to its GDP

Ratio of a country's 2004 stock market trading volumes to GDP

The ratio of the number of a country's listed domestic firms in 2004 to millions of population

The ratio of annual capital raised in a country through IPOs in 2004 to its GDP

The block premiums are computed by taking the difference between the price per share paid for the control block and the exchange price two days after the announcement of the control transaction, dividing by the exchange price and multiplying by the ratio of the proportion of cash flow rights represented in the controlling block, as Dyck and Zingales (2004) describe.

Average percentage of common shares not owned by the top three shareholders in the ten largest non-financial, privately-owned domestic firms in a given country.

Index of the extent to which business executives in a country agree with the statement "Stock markets are open to new firms and medium-sized firms." Scale from one (strongly agree) through seven (strongly disagree)

Index averaging other indices that measure market size, market access, market efficiency, and market stability in 2005.

Index of factors measuring the size of capital markets in 2005

Index of factors measuring the ease of accessing capital markets in 2005

Index of factors measuring the efficiency of capital markets in 2005

Index of factors measuring the stability of capital markets in 2005
La Porta et al. (1998) (original), revised in Djankov et al. (2005)

Political Risk Services (1996); ternational Country Risk Guide

LSV (1996: 1130-31); CIA Factbook (2006)

Derived from data downloaded from World Bank Data and Statistics Web site.

Derived from GDP variables downloaded from World Bank Data and Statistics the

World Bank (2006c)

World Bank (2006c)

World Bank (2006c)

World Bank (2006c)

Dyck and Zingales (2004)

La Porta et al. (2006)

Schwab et al. (1999)

World Bank (2006c)

World Bank (2006c)

World Bank (2006c)

World Bank (2006c)

World Bank (2006c) 
Table 2

Resource-based securities law enforcement data: staffing/population and budget/GDP.

This table provides resource-based data to measure public enforcement intensity based on securities regulators' staffing/population and budget/GDP levels. The basic sample, in column 1, shows the staffing levels per million of a country's population from How Countries Supervise (2006, 2007). Column 2 extends the sample to countries that provide their securities regulators' budget through other sources (indicated in Table 1). Column 3 adds in extrapolated staffing levels for integrated regulators: Some nations, such as the United Kingdom, have a single financial markets regulator, one that regulates securities markets, banking, and sometimes regulators that do not break out their securities regulators' budgets from the integrated budget; we extrapolated the securities regulatory budget using the median proportion of securities regulator budget/integrated regulatory budget for those nations for which we could determine both. Columns 4,5 , and 6 show resource-based securities regulator data for the regulators' budgets, measured analogously. Columns 7 and 8 show previously assembled measures of public enforcement based on the regulator's formal authority, such as independence from the executive, rule-making authority, authority to bring criminal actions, and so on.

Resource-based measures of public enforcement

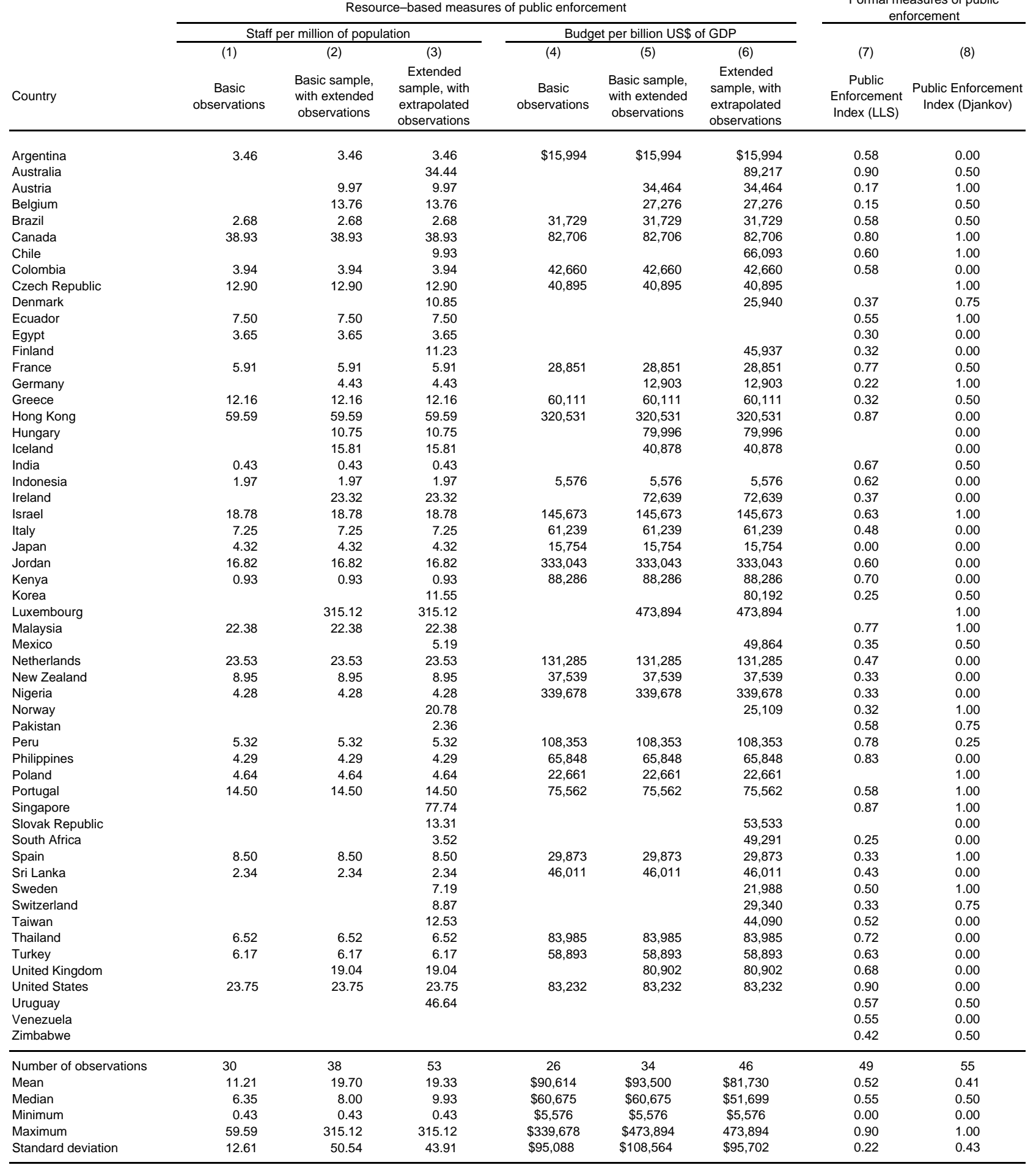


Table 3

Pairwise Correlation Matrix for Key Enforcement Variables

In this table we report pairwise correlations between the key enforcement variables. The six resource-based measures of enforcement correlate at levels on.51 and higher. The resource-based measures of public enforcement do not correlate as strongly with enforcement measures derived from the regulators' formal powers, with the correlations at levels ranging from -0.22 to 0.41 . Of note is that the two public enforcement measures based on formal powers of the regulator correlate negatively.

\begin{tabular}{|c|c|c|c|c|c|c|c|c|c|c|c|c|}
\hline & Disclosure & Liability & $\begin{array}{c}\text { Anti-director } \\
\text { rights } \\
\text { (original) }\end{array}$ & $\begin{array}{c}\text { Judicial } \\
\text { efficiency }\end{array}$ & $\begin{array}{c}\text { Public } \\
\text { enforcement } \\
\text { (LLS) }\end{array}$ & $\begin{array}{c}\text { Public } \\
\text { enforcement } \\
\text { (Djankov) }\end{array}$ & $\begin{array}{c}\text { Regulatory } \\
\text { staff/population } \\
\text { (basic sample) }\end{array}$ & $\begin{array}{c}\text { Regulatory } \\
\text { staff/population } \\
\text { (extended sample) }\end{array}$ & $\begin{array}{c}\text { Regulatory } \\
\text { staff/population } \\
\text { (extrapolated sample) }\end{array}$ & $\begin{array}{c}\text { Regulatory } \\
\text { budget/GDP } \\
\text { (basic sample) }\end{array}$ & $\begin{array}{c}\text { Regulatory } \\
\text { budget/GDP } \\
\text { (extended sample) }\end{array}$ & $\begin{array}{c}\text { Regulatory } \\
\text { budget/GDP } \\
\text { (extrapolated) }\end{array}$ \\
\hline Disclosure & 1.00 & & & & & & & & & & & \\
\hline Liability standards & 0.55 & 1.00 & & & & & & & & & & \\
\hline Anti-director rights & 0.52 & 0.50 & 1.00 & & & & & & & & & \\
\hline Judicial efficiency & 0.25 & 0.22 & 0.21 & 1.00 & & & & & & & & \\
\hline Public enforcement (LLS) & 0.33 & 0.31 & 0.37 & -0.11 & 1.00 & & & & & & & \\
\hline Public enforcement (Djankov) & -0.15 & -0.07 & 0.06 & 0.24 & -0.03 & 1.00 & & & & & & \\
\hline Regulatory staff/population (basic sample) & 0.39 & 0.45 & 0.40 & 0.55 & 0.39 & 0.16 & 1.00 & & & & & \\
\hline Regulatory staff/population (extended sample) & 0.40 & 0.44 & 0.38 & 0.53 & 0.33 & 0.25 & 1.00 & 1.00 & & & & \\
\hline Regulatory staff/population (extrapolated sample) & 0.26 & 0.30 & 0.25 & 0.44 & 0.41 & 0.23 & 1.00 & 1.00 & 1.00 & & & \\
\hline Regulatory budget/GDP (basic sample) & 0.25 & 0.04 & -0.06 & 0.34 & 0.15 & -0.22 & 0.51 & 0.51 & 0.51 & 1.00 & & \\
\hline Regulatory budget/GDP (extended sample) & 0.30 & 0.09 & 0.06 & 0.22 & 0.25 & -0.02 & 0.51 & 0.69 & 0.69 & 1.00 & 1.00 & \\
\hline Regulatory budget/GDP (extrapolated sample) & 0.27 & 0.10 & 0.06 & 0.12 & 0.29 & -0.07 & 0.51 & 0.69 & 0.68 & 1.00 & 1.00 & 1.00 \\
\hline
\end{tabular}


Table 4

Resource-based enforcement and formal powers-based enforcement as predicting financial market size

In this table, we test whether measures of the level of a nation's resource-based public enforcement predict the level of a nation's financial market strength. We use two measures here of resource-based public enforcement: the securities regulator's staffing level per million of population and the securities regulator's budget/GDP. Financial outcomes are the country's stock market capitalization/GDP, stock trading volume/GDP, number of domestic firms/population, and number of IPOs/GDP, all standard measures of financial development. We control for judicial efficiency, corporate law (via the anti-director rights index), and GDP/capita. We run five models for each pairing of enforcement and outcomes. In the first model, in column 1 for each of the four pairings, we see whether preexisting formal measures of regulatory powers predict the financial outcomes. In the second and fourth models, in columns 2 and 4 , we substitute the four pairings, we see whether preexisting formal measures of regulatory powers predict the financial outcomes. In the second and fourth models, in columns 2 and 4 , we substitute the
resource-based measure of public enforcement. In these four pairings, resource-based enforcement is significant in seven of its eight appearances. In the third and fifth models, in columns 3 and 5 , we run both the formal measure of public enforcement and the resource-based measure. Formal public enforcement is significant in these models only once in its eight appearances. The resource-based measure is significant in seven of these mini-horse races. Robust standard errors are in parentheses; the constant is not reported.

\begin{tabular}{|c|c|c|c|c|c|c|c|c|c|c|}
\hline & \multicolumn{5}{|c|}{$\begin{array}{c}\text { Panel } \mathrm{A} \\
\text { Dependent variable }=\text { Stock market capitalization/GDP }\end{array}$} & \multicolumn{5}{|c|}{$\begin{array}{c}\text { Panel } \mathrm{B} \\
\text { Dependent variable }=\text { Trading volume/GDP }\end{array}$} \\
\hline & $\begin{array}{c}\text { Formal public } \\
\text { enforcement }\end{array}$ & $\begin{array}{l}\text { Staffing } \\
\text { resources/ } \\
\text { population }\end{array}$ & $\begin{array}{l}\text { Staffing/ } \\
\text { population and } \\
\text { formal }\end{array}$ & $\begin{array}{l}\text { Budget } \\
\text { resources/ } \\
\text { GDP }\end{array}$ & $\begin{array}{l}\text { Budget/GDP } \\
\text { and formal }\end{array}$ & $\begin{array}{l}\text { Formal public } \\
\text { enforcement }\end{array}$ & $\begin{array}{l}\text { Staffing } \\
\text { resources/ } \\
\text { population }\end{array}$ & $\begin{array}{l}\text { Staffing/ } \\
\text { population and } \\
\text { formal }\end{array}$ & $\begin{array}{l}\text { Budget } \\
\text { resources/ } \\
\text { GDP }\end{array}$ & $\begin{array}{l}\text { Budget/GDP } \\
\text { and formal }\end{array}$ \\
\hline & (1) & (2) & (3) & (4) & (5) & (1) & (2) & (3) & (4) & (5) \\
\hline $\begin{array}{l}\text { Regulatory staff/population } \\
\text { (extended sample) }\end{array}$ & - & $\begin{array}{r}0.015^{\mathrm{a}} \\
(0.0033)\end{array}$ & $\begin{array}{c}0.011^{b} \\
(0.0041)\end{array}$ & - & - & - & $\begin{array}{l}1.95^{\mathrm{a}} \\
(0.57)\end{array}$ & $\begin{array}{l}1.60^{b} \\
(0.74)\end{array}$ & - & - \\
\hline $\begin{array}{r}\text { Regulatory budget/GDP } \\
\text { (extended sample) }\end{array}$ & - & - & - & $\begin{array}{c}0.0017^{a} \\
(0.00054)\end{array}$ & $\begin{array}{c}0.0012^{b} \\
(0.00045)\end{array}$ & - & - & - & $\begin{array}{r}0.25^{\mathrm{a}} \\
(0.080)\end{array}$ & $\begin{array}{l}0.20^{\mathrm{b}} \\
(0.08)\end{array}$ \\
\hline Formal public enforcement (LLS) & $\begin{array}{l}0.34^{\mathrm{c}} \\
(0.20)\end{array}$ & - & $\begin{array}{l}0.38 \\
(0.22)\end{array}$ & - & $\begin{array}{l}0.50^{\mathrm{b}} \\
(0.20)\end{array}$ & $\begin{array}{l}39.56 \\
(30.01)\end{array}$ & - & $\begin{array}{l}33.93 \\
(42.28)\end{array}$ & - & $\begin{array}{l}47.72 \\
(40.27)\end{array}$ \\
\hline Anti-director rights & $\begin{array}{l}0.071^{b} \\
(0.035)\end{array}$ & $\begin{array}{l}0.068^{\mathrm{b}} \\
(0.031)\end{array}$ & $\begin{array}{l}0.044 \\
(0.030)\end{array}$ & $\begin{array}{r}0.10^{\mathrm{a}} \\
(0.037)\end{array}$ & $\begin{array}{l}0.061^{\mathrm{c}} \\
(0.035)\end{array}$ & $\begin{array}{l}7.86 \\
(4.73)\end{array}$ & $\begin{array}{l}10.35^{\mathrm{c}} \\
(5.23)\end{array}$ & $\begin{array}{l}8.21 \\
(5.55)\end{array}$ & $\begin{array}{l}12.57^{\mathrm{b}} \\
(5.42)\end{array}$ & $\begin{array}{l}8.60 \\
(5.61)\end{array}$ \\
\hline Judicial efficiency & $\begin{array}{l}0.052^{b} \\
(0.024)\end{array}$ & $\begin{array}{l}0.021 \\
(0.018)\end{array}$ & $\begin{array}{l}0.038 \\
(0.023)\end{array}$ & $\begin{array}{c}-0.0027 \\
(0.027)\end{array}$ & $\begin{array}{l}0.026 \\
(0.028)\end{array}$ & $\begin{array}{l}-2.10 \\
(5.42)\end{array}$ & $\begin{array}{l}-2.56 \\
(3.04)\end{array}$ & $\begin{array}{l}-1.00 \\
(4.50)\end{array}$ & $\begin{array}{l}-8.17^{b} \\
(3.81)\end{array}$ & $\begin{array}{l}-5.44 \\
(5.37)\end{array}$ \\
\hline Ln GDP per capita & $\begin{array}{c}0.10^{\mathrm{a}} \\
(0.022)\end{array}$ & $\begin{array}{l}0.044^{\mathrm{b}} \\
(0.020)\end{array}$ & $\begin{array}{l}0.060^{\mathrm{a}} \\
(0.019)\end{array}$ & $\begin{array}{r}0.15^{\mathrm{a}} \\
(0.035)\end{array}$ & $\begin{array}{r}0.14^{\mathrm{a}} \\
(0.028)\end{array}$ & $\begin{array}{c}21.43^{\mathrm{a}} \\
(7.08)\end{array}$ & $\begin{array}{l}8.27^{\mathrm{c}} \\
(4.21)\end{array}$ & $\begin{array}{l}9.74^{\mathrm{b}} \\
(4.44)\end{array}$ & $\begin{array}{c}26.80^{\mathrm{a}} \\
(5.71)\end{array}$ & $\begin{array}{c}25.86^{\mathrm{a}} \\
(5.76)\end{array}$ \\
\hline $\begin{array}{l}\text { Observations } \\
\text { MSE }\end{array}$ & $\begin{array}{c}49 \\
0.27\end{array}$ & $\begin{array}{c}33 \\
0.21\end{array}$ & $\begin{array}{c}33 \\
0.20\end{array}$ & $\begin{array}{c}29 \\
0.23\end{array}$ & $\begin{array}{c}29 \\
0.22\end{array}$ & $\begin{array}{c}49 \\
56.89\end{array}$ & $\begin{array}{c}33 \\
33.18\end{array}$ & $\begin{array}{c}33 \\
33.24\end{array}$ & $\begin{array}{c}29 \\
35.10\end{array}$ & $\begin{array}{c}29 \\
34.52\end{array}$ \\
\hline \multirow[t]{4}{*}{ Adjusted $\mathrm{R}^{2}$} & 0.48 & 0.67 & 0.69 & 0.59 & 0.65 & 0.18 & 0.51 & 0.51 & 0.48 & 0.49 \\
\hline & \multicolumn{5}{|c|}{$\begin{array}{c}\text { Panel C } \\
\text { Dependent variable }=\text { Domestic firms/population }\end{array}$} & \multicolumn{5}{|c|}{$\begin{array}{c}\text { Panel } \mathrm{D} \\
\text { Dependent variable }=I P O \mathrm{I} / \mathrm{GDP}\end{array}$} \\
\hline & $\begin{array}{l}\text { Formal public } \\
\text { enforcement }\end{array}$ & $\begin{array}{l}\text { Staffing } \\
\text { resources/ } \\
\text { population }\end{array}$ & $\begin{array}{l}\text { Staffing/ } \\
\text { population and } \\
\text { formal }\end{array}$ & $\begin{array}{l}\text { Budget } \\
\text { resources/ } \\
\text { GDP }\end{array}$ & $\begin{array}{l}\text { Budget/GDP } \\
\text { and formal }\end{array}$ & $\begin{array}{l}\text { Formal public } \\
\text { enforcement }\end{array}$ & $\begin{array}{l}\text { Staffing } \\
\text { resources/ } \\
\text { population }\end{array}$ & $\begin{array}{l}\text { Staffing/ } \\
\text { population and } \\
\text { formal }\end{array}$ & $\begin{array}{l}\text { Budget } \\
\text { resources/ } \\
\text { GDP }\end{array}$ & $\begin{array}{l}\text { Budget/GDP } \\
\text { and formal }\end{array}$ \\
\hline & (1) & (2) & (3) & (4) & (5) & (1) & (2) & (3) & (4) & (5) \\
\hline $\begin{array}{l}\text { Regulatory staff/population } \\
\text { (extended sample) }\end{array}$ & - & $\begin{array}{l}0.038^{\mathrm{a}} \\
(0.009)\end{array}$ & $\begin{array}{l}0.036^{\mathrm{a}} \\
(0.011)\end{array}$ & - & - & - & $\begin{array}{r}0.13^{\mathrm{a}} \\
(0.028)\end{array}$ & $\begin{array}{r}0.14^{\mathrm{a}} \\
(0.040)\end{array}$ & - & - \\
\hline $\begin{array}{r}\text { Regulatory budget/GDP } \\
\text { (extended sample) }\end{array}$ & - & - & - & $\begin{array}{l}0.0036 \\
(0.0021)\end{array}$ & $\begin{array}{l}0.0028 \\
(0.0023)\end{array}$ & - & - & - & $\begin{array}{c}0.010^{\mathrm{b}} \\
(0.0044)\end{array}$ & $\begin{array}{l}0.0084^{c} \\
(0.0047)\end{array}$ \\
\hline Formal public enforcement (LLS) & $\begin{array}{l}0.64 \\
(0.48)\end{array}$ & - & $\begin{array}{l}0.13 \\
(0.71)\end{array}$ & - & $\begin{array}{l}0.85 \\
(0.78)\end{array}$ & $\begin{array}{l}3.72^{\mathrm{b}} \\
(1.55)\end{array}$ & - & $\begin{array}{l}-0.43 \\
(2.14)\end{array}$ & - & $\begin{array}{l}1.97 \\
(2.24)\end{array}$ \\
\hline Anti-director rights & $\begin{array}{c}0.18^{\mathrm{b}} \\
(0.086)\end{array}$ & $\begin{array}{l}0.049 \\
(0.084)\end{array}$ & $\begin{array}{r}0.040 \\
(0.10)\end{array}$ & $\begin{array}{l}0.14 \\
(0.091)\end{array}$ & $\begin{array}{r}0.074 \\
(0.12)\end{array}$ & $\begin{array}{l}0.31 \\
(0.24)\end{array}$ & $\begin{array}{l}0.39 \\
(0.35)\end{array}$ & $\begin{array}{l}0.41 \\
(0.34)\end{array}$ & $\begin{array}{l}0.68 \\
(0.40)\end{array}$ & $\begin{array}{l}0.51 \\
(0.38)\end{array}$ \\
\hline Judicial efficiency & $\begin{array}{c}0.26^{\mathrm{a}} \\
(0.075)\end{array}$ & $\begin{array}{c}0.20^{\mathrm{b}} \\
(0.074)\end{array}$ & $\begin{array}{c}0.20^{\mathrm{b}} \\
(0.081)\end{array}$ & $\begin{array}{l}0.15 \\
(0.091)\end{array}$ & $\begin{array}{l}0.20^{\mathrm{c}} \\
(0.10)\end{array}$ & $\begin{array}{l}0.04 \\
(0.22)\end{array}$ & $\begin{array}{l}-0.26 \\
(0.20)\end{array}$ & $\begin{array}{l}-0.28 \\
(0.26)\end{array}$ & $\begin{array}{l}-0.40 \\
(0.30)\end{array}$ & $\begin{array}{l}-0.29 \\
(0.35)\end{array}$ \\
\hline Ln GDP per capita & $\begin{array}{l}0.29^{\mathrm{a}} \\
(0.11)\end{array}$ & $\begin{array}{l}0.17 \\
(0.11)\end{array}$ & $\begin{array}{l}0.17 \\
(0.13)\end{array}$ & $\begin{array}{l}0.42^{\mathrm{b}} \\
(0.17)\end{array}$ & $\begin{array}{l}0.40^{b} \\
(0.16)\end{array}$ & $\begin{array}{l}1.22^{\mathrm{a}} \\
(0.27)\end{array}$ & $\begin{array}{l}0.72^{\mathrm{a}} \\
(0.26)\end{array}$ & $\begin{array}{l}0.70^{b} \\
(0.28)\end{array}$ & $\begin{array}{l}1.56^{\mathrm{a}} \\
(0.40)\end{array}$ & $\begin{array}{l}1.52^{\mathrm{a}} \\
(0.41)\end{array}$ \\
\hline Observations & 49 & 33 & 33 & 29 & 29 & 49 & 33 & 33 & 29 & 29 \\
\hline MSE & 0.66 & 0.65 & 0.66 & 0.71 & 0.71 & 2.57 & 2.27 & 2.31 & 2.63 & 2.66 \\
\hline Adjusted $R$-squared & 0.66 & 0.68 & 0.67 & 0.64 & 0.64 & 0.34 & 0.47 & 0.45 & 0.32 & 0.31 \\
\hline
\end{tabular}


Table 5

Staffing/population-based public enforcement in horse race with private enforcement

In this table we present horse races between resource-based public enforcement and private enforcement variables. Panel A uses market capitalization/GDP as the outcome variable, Panel B trading volume/GDP as the outcome variable, Panel C the number of domestic firms/population, and Panel D IPOs/GDP. We run nine models with each of the four outcome variables. Column 1 tests public enforcement alone, then we add disclosure in column 2, liability standards in column 3 , and both disclosure and liability standards in column 4 . Next we add a resource-based measure of public enforcement, the extended sample of the securities regulators' staffing/population levels. Columns 5 and 6 run the public enforcement variables, with resource-based enforcement alone first in column 5 , and then with formal public enforcement, measured by the securities regulators' powers, in column 6 . Columns 7,8

and 9 check for the robustness of the resource-based enforcement measure in horse races between public and private enforcement: i.e., the staff/population-based resources variable runs against disclosure in column 7 , against liability in column 8 , then against both private enforcement measures in column 9. We add three conditioning variables to each model: wealth, judicial efficiency, and anti-directors rights. The resource-based measure is significant in 19 of the 20 models in which it appears; disclosure is significant without resource-based enforcement in four of eight runs, and insignificant in five out of the eight models in which it runs against resource-based enforcement. The coefficient on the liability standards variable often is negative in the face of the resource-based measure of public enforcement, significantly so three times. Robust standard errors are in parentheses; the constant is not reported.

Panel A: Dependent variable $=$ Market capitalization to GDP (2004)

\begin{tabular}{|c|c|c|c|c|c|c|c|c|c|}
\hline \multirow[b]{2}{*}{$\begin{array}{l}\text { Regulatory staff/population } \\
\text { (extended sample) }\end{array}$} & & & & & & & & & \\
\hline & (1) & (2) & (3) & (4) & $\begin{array}{l}(5) \\
6.55^{\mathrm{a}} \\
(1.99)\end{array}$ & $\begin{array}{l}(6) \\
6.48^{\mathrm{a}} \\
(2.27)\end{array}$ & $\begin{array}{l}(7) \\
6.30^{\mathrm{a}} \\
(2.16)\end{array}$ & $\begin{array}{l}(8) \\
7.10^{\mathrm{a}} \\
(1.94)\end{array}$ & $\begin{array}{l}(9) \\
6.81^{\mathrm{a}} \\
(2.02)\end{array}$ \\
\hline Formal public enforcement & $\begin{array}{l}127.12^{\mathrm{C}} \\
(66.11)\end{array}$ & $\begin{array}{l}90.62 \\
(71.23)\end{array}$ & $\begin{array}{r}126.38 \\
(76.39)\end{array}$ & $\begin{array}{l}96.21 \\
(77.96)\end{array}$ & & $\begin{array}{c}4.88 \\
(42.76)\end{array}$ & & & \\
\hline Disclosure & & $\begin{array}{c}108.25^{b} \\
(44.00)\end{array}$ & & $\begin{array}{l}114.76^{\mathrm{b}} \\
(43.46)\end{array}$ & & & $\begin{array}{l}34.95 \\
(31.78)\end{array}$ & & $\begin{array}{l}60.21^{b} \\
(25.92)\end{array}$ \\
\hline Liability standards & & & $\begin{array}{l}2.02 \\
(36.42)\end{array}$ & $\begin{array}{l}-21.13 \\
(37.97)\end{array}$ & & & & $\begin{array}{l}-56.92 \\
(39.44)\end{array}$ & $\begin{array}{l}-71.23^{\mathrm{C}} \\
(36.95)\end{array}$ \\
\hline Anti-directors rights (rev.) & $\begin{array}{l}21.93^{\mathrm{C}} \\
(10.91)\end{array}$ & $\begin{array}{l}9.30 \\
(12.07)\end{array}$ & $\begin{array}{l}21.74^{\mathrm{C}} \\
(12.03)\end{array}$ & $\begin{array}{l}10.48 \\
(12.70)\end{array}$ & $\begin{array}{l}9.31 \\
(7.33)\end{array}$ & $\begin{array}{l}9.27 \\
(7.59)\end{array}$ & $\begin{array}{l}6.46 \\
(8.59)\end{array}$ & $\begin{array}{r}13.41 \\
(8.39)\end{array}$ & $\begin{array}{l}9.54 \\
(8.92)\end{array}$ \\
\hline Judicial efficiency & $\begin{array}{l}11.69^{\mathrm{C}} \\
(5.51)\end{array}$ & $\begin{array}{l}8.72^{\mathrm{c}} \\
(5.01)\end{array}$ & $\begin{array}{l}11.66^{\mathrm{C}} \\
(5.87)\end{array}$ & $\begin{array}{l}8.89 \\
(5.31)\end{array}$ & $\begin{array}{l}0.45 \\
(3.79)\end{array}$ & $\begin{array}{l}0.65 \\
(4.25)\end{array}$ & $\begin{array}{l}-0.22 \\
(3.48)\end{array}$ & $\begin{array}{l}0.43 \\
(3.71)\end{array}$ & $\begin{array}{l}-0.73 \\
(3.60)\end{array}$ \\
\hline Wealth control & $\begin{array}{l}18.19^{\mathrm{C}} \\
(10.43)\end{array}$ & $\begin{array}{l}19.13^{\mathrm{c}} \\
(9.86)\end{array}$ & $\begin{array}{l}18.13 \\
(10.95)\end{array}$ & $\begin{array}{l}19.78^{\mathrm{C}} \\
(10.41)\end{array}$ & $\begin{array}{l}-12.38 \\
(9.47)\end{array}$ & $\begin{array}{l}-12.00 \\
(10.77)\end{array}$ & $\begin{array}{l}-10.36 \\
(9.62)\end{array}$ & $\begin{array}{l}-13.70 \\
(9.77)\end{array}$ & $\begin{array}{l}-10.57 \\
(9.34)\end{array}$ \\
\hline Observations & 47 & 47 & 47 & 47 & 33 & 33 & 33 & 33 & 33 \\
\hline MSE & 70.85 & 69.02 & 71.70 & 69.73 & 47.66 & 48.52 & 47.98 & 46.30 & 45.56 \\
\hline \multirow[t]{4}{*}{ Adjusted $R$-Squared } & 0.34 & 0.37 & 0.32 & 0.36 & 0.72 & 0.70 & 0.71 & 0.73 & 0.74 \\
\hline & \multicolumn{9}{|c|}{ Panel B: Dependent variable $=$ Trading volume to GDP (2004) } \\
\hline & \multicolumn{4}{|c|}{ Without extended staffing/population variable } & \multicolumn{5}{|c|}{ With extended staffing/population variable } \\
\hline & (1) & (2) & (3) & (4) & (5) & (6) & (7) & (8) & (9) \\
\hline $\begin{array}{l}\text { Regulatory staff/population } \\
\text { (extended sample) }\end{array}$ & & & & & $\begin{array}{l}2.83^{\mathrm{a}} \\
(0.98)\end{array}$ & $\begin{array}{l}2.05 \\
(1.23)\end{array}$ & $\begin{array}{l}2.21^{\mathrm{C}} \\
(1.15)\end{array}$ & $\begin{array}{l}2.71^{\mathrm{b}} \\
(1.14)\end{array}$ & $\begin{array}{l}2.23^{\mathrm{c}} \\
(1.24)\end{array}$ \\
\hline Formal public enforcement & $\begin{array}{l}62.65^{\mathrm{c}} \\
(36.26)\end{array}$ & $\begin{array}{l}27.51 \\
(33.89)\end{array}$ & $\begin{array}{l}49.90 \\
(38.63)\end{array}$ & $\begin{array}{l}21.65 \\
(36.62)\end{array}$ & & $\begin{array}{l}59.19 \\
(41.78)\end{array}$ & & & \\
\hline Disclosure & & $\begin{array}{l}96.69^{\mathrm{a}} \\
(28.00)\end{array}$ & & $\begin{array}{l}90.79^{\mathrm{a}} \\
(29.16)\end{array}$ & & & $\begin{array}{l}81.26^{b} \\
(32.29)\end{array}$ & & $\begin{array}{l}82.06^{b} \\
(29.80)\end{array}$ \\
\hline Liability standards & & & $\begin{array}{l}33.82 \\
(27.78)\end{array}$ & $\begin{array}{l}21.24 \\
(28.65)\end{array}$ & & & & $\begin{array}{c}12.01 \\
(36.14)\end{array}$ & $\begin{array}{c}-2.50 \\
(33.04)\end{array}$ \\
\hline Anti-directors rights (rev.) & $\begin{array}{c}11.28 \\
(7.17)\end{array}$ & $\begin{array}{l}3.79 \\
(7.27)\end{array}$ & $\begin{array}{l}8.64 \\
(7.98)\end{array}$ & $\begin{array}{l}2.59 \\
(7.83)\end{array}$ & $\begin{array}{c}10.32 \\
(6.95)\end{array}$ & $\begin{array}{l}9.94 \\
(6.80)\end{array}$ & $\begin{array}{l}5.22 \\
(6.95)\end{array}$ & $\begin{array}{l}9.57 \\
(7.93)\end{array}$ & $\begin{array}{l}5.33 \\
(7.82)\end{array}$ \\
\hline Judicial efficiency & $\begin{array}{l}4.88 \\
(3.53)\end{array}$ & $\begin{array}{l}2.50 \\
(3.15)\end{array}$ & $\begin{array}{l}4.35 \\
(3.75)\end{array}$ & $\begin{array}{l}2.32 \\
(3.24)\end{array}$ & $\begin{array}{l}-0.49 \\
(3.77)\end{array}$ & $\begin{array}{l}1.88 \\
(4.61)\end{array}$ & $\begin{array}{l}-1.86 \\
(3.15)\end{array}$ & $\begin{array}{l}-0.47 \\
(3.93)\end{array}$ & $\begin{array}{l}-1.88 \\
(3.21)\end{array}$ \\
\hline Wealth control & $\begin{array}{c}22.73^{\mathrm{a}} \\
(6.16)\end{array}$ & $\begin{array}{c}23.89^{\mathrm{a}} \\
(6.06)\end{array}$ & $\begin{array}{c}21.85^{\mathrm{a}} \\
(6.30)\end{array}$ & $\begin{array}{c}23.27^{\mathrm{a}} \\
(6.14)\end{array}$ & $\begin{array}{r}10.73 \\
(7.09)\end{array}$ & $\begin{array}{c}15.28^{b} \\
(6.92)\end{array}$ & $\begin{array}{c}15.99^{b} \\
(6.65)\end{array}$ & $\begin{array}{c}11.05 \\
(7.37)\end{array}$ & $\begin{array}{c}15.98^{\mathrm{b}} \\
(6.87)\end{array}$ \\
\hline Observations & 44 & 44 & 44 & 44 & 32 & 32 & 32 & 32 & 32 \\
\hline MSE & 49.27 & 47.44 & 49.31 & 47.84 & 42.42 & 41.61 & 40.35 & 43.12 & 41.14 \\
\hline Adjusted $R$-Squared & 0.30 & 0.35 & 0.30 & 0.34 & 0.50 & 0.52 & 0.55 & 0.49 & 0.53 \\
\hline
\end{tabular}


Table 5

Panel C: Number of domestic firms/population (2004)

\begin{tabular}{|c|c|c|c|c|c|c|c|c|c|}
\hline \multirow{3}{*}{$\begin{array}{l}\text { Regulatory staff/population } \\
\text { (extended sample) }\end{array}$} & \multicolumn{4}{|c|}{ Without extended staffing/population variable } & \multicolumn{5}{|c|}{ With Extended Staffing/population Variable } \\
\hline & (1) & $(2)$ & (3) & (4) & $(5)$ & (6) & $(7)$ & (8) & $(9)$ \\
\hline & & & & & $\begin{array}{l}0.20^{\mathrm{a}} \\
(0.04)\end{array}$ & $\begin{array}{l}0.22^{a} \\
(0.05)\end{array}$ & $\begin{array}{l}0.21^{\mathrm{a}} \\
(0.04)\end{array}$ & $\begin{array}{l}0.21^{\mathrm{a}} \\
(0.05)\end{array}$ & $\begin{array}{l}0.21^{\mathrm{a}} \\
(0.05)\end{array}$ \\
\hline Formal public enforcement & $\begin{array}{l}5.59^{b} \\
(2.27)\end{array}$ & $\begin{array}{l}5.28^{b} \\
(2.15)\end{array}$ & $\begin{array}{l}5.47^{b} \\
(2.48)\end{array}$ & $\begin{array}{l}5.24^{b} \\
(2.35)\end{array}$ & & $\begin{array}{l}-1.53 \\
(2.01)\end{array}$ & & & \\
\hline Disclosure & & $\begin{array}{c}0.93 \\
(1.99)\end{array}$ & & $\begin{array}{c}0.88 \\
(2.03)\end{array}$ & & & $\begin{array}{l}-0.73 \\
(1.46)\end{array}$ & & $\begin{array}{l}-0.43 \\
(1.47)\end{array}$ \\
\hline Liability standards & & & $\begin{array}{c}0.34 \\
(1.79)\end{array}$ & $\begin{array}{c}0.16 \\
(1.84)\end{array}$ & & & & $\begin{array}{l}-0.94 \\
(1.45)\end{array}$ & $\begin{array}{l}-0.83 \\
(1.51)\end{array}$ \\
\hline Anti-directors rights (rev.) & $\begin{array}{l}0.89^{b} \\
(0.36)\end{array}$ & $\begin{array}{c}0.78 \\
(0.51)\end{array}$ & $\begin{array}{l}0.86^{\mathrm{c}} \\
(0.45)\end{array}$ & $\begin{array}{c}0.77 \\
(0.56)\end{array}$ & $\begin{array}{c}0.59 \\
(0.36)\end{array}$ & $\begin{array}{c}0.60 \\
(0.37)\end{array}$ & $\begin{array}{c}0.64 \\
(0.45)\end{array}$ & $\begin{array}{c}0.65 \\
(0.41)\end{array}$ & $\begin{array}{c}0.68 \\
(0.47)\end{array}$ \\
\hline Judicial efficiency & $\begin{array}{l}0.49^{b} \\
(0.21)\end{array}$ & $\begin{array}{l}0.47^{\mathrm{b}} \\
(0.20)\end{array}$ & $\begin{array}{l}0.49^{b} \\
(0.22)\end{array}$ & $\begin{array}{l}0.46^{\mathrm{b}} \\
(0.20)\end{array}$ & $\begin{array}{c}0.07 \\
(0.19)\end{array}$ & $\begin{array}{c}0.01 \\
(0.24)\end{array}$ & $\begin{array}{c}0.08 \\
(0.18)\end{array}$ & $\begin{array}{c}0.07 \\
(0.20)\end{array}$ & $\begin{array}{c}0.08 \\
(0.19)\end{array}$ \\
\hline Wealth control & $\begin{array}{l}1.08^{b} \\
(0.46)\end{array}$ & $\begin{array}{l}1.09^{b} \\
(0.46)\end{array}$ & $\begin{array}{l}1.07^{b} \\
(0.47)\end{array}$ & $\begin{array}{l}1.08^{b} \\
(0.47)\end{array}$ & $\begin{array}{l}-0.01 \\
(0.42)\end{array}$ & $\begin{array}{l}-0.12 \\
(0.40)\end{array}$ & $\begin{array}{l}-0.05 \\
(0.41)\end{array}$ & $\begin{array}{l}-0.03 \\
(0.45)\end{array}$ & $\begin{array}{l}-0.05 \\
(0.42)\end{array}$ \\
\hline Observations & 47 & 47 & 47 & 47 & 33 & 33 & 33 & 33 & 33 \\
\hline MSE & 2.48 & 2.50 & 2.51 & 2.53 & 1.94 & 1.95 & 1.97 & 1.96 & 2.00 \\
\hline Adjusted $R$-Squared & 0.48 & 0.47 & 0.47 & 0.46 & 0.66 & 0.65 & 0.65 & 0.65 & 0.64 \\
\hline
\end{tabular}

Panel D: Dependent variable $=I P O$ value/GDP (2004)

\begin{tabular}{|c|c|c|c|c|c|c|c|c|c|}
\hline & \multicolumn{4}{|c|}{ Without extended staffing/population variable } & \multicolumn{5}{|c|}{ With extended staffing/population variable } \\
\hline & $(1)$ & $(2)$ & $(3)$ & (4) & (5) & (6) & $(7)$ & (8) & $(9)$ \\
\hline Regulatory staff/population & & & & & $0.19^{\mathrm{b}}$ & $0.26^{b}$ & $0.21^{\mathrm{b}}$ & $0.25^{\mathrm{a}}$ & $0.25^{a}$ \\
\hline (extended sample) & & & & & $(0.09)$ & $(0.10)$ & $(0.09)$ & $(0.07)$ & $(0.07)$ \\
\hline Formal public enforcement & $\begin{array}{l}5.10 \\
(3.33)\end{array}$ & $\begin{array}{l}4.57 \\
(2.87)\end{array}$ & $\begin{array}{l}5.92 \\
(3.69)\end{array}$ & $\begin{array}{l}5.12 \\
(3.17)\end{array}$ & & $\begin{array}{l}-5.12 \\
(3.66)\end{array}$ & & & \\
\hline Disclosure & & $\begin{array}{l}1.52 \\
(3.32)\end{array}$ & & $\begin{array}{l}2.85 \\
(3.69)\end{array}$ & & & $\begin{array}{l}-3.24 \\
(4.61)\end{array}$ & & $\begin{array}{l}-0.53 \\
(4.50)\end{array}$ \\
\hline Liability Standards & & & $\begin{array}{l}-2.13 \\
(1.94)\end{array}$ & $\begin{array}{l}-2.67 \\
(2.26)\end{array}$ & & & & $\begin{array}{c}-5.18^{b} \\
(2.03)\end{array}$ & $\begin{array}{c}-5.05^{\mathrm{b}} \\
(2.13)\end{array}$ \\
\hline Anti-directors rights (rev.) & $\begin{array}{l}1.59^{b} \\
(0.73)\end{array}$ & $\begin{array}{l}1.49^{b} \\
(0.69)\end{array}$ & $\begin{array}{l}1.70^{\mathrm{b}} \\
(0.77)\end{array}$ & $\begin{array}{l}1.54^{b} \\
(0.68)\end{array}$ & $\begin{array}{l}0.65 \\
(0.58)\end{array}$ & $\begin{array}{l}0.67 \\
(0.57)\end{array}$ & $\begin{array}{l}0.74 \\
(0.57)\end{array}$ & $\begin{array}{l}0.68 \\
(0.50)\end{array}$ & $\begin{array}{l}0.70 \\
(0.44)\end{array}$ \\
\hline Judicial efficiency & $\begin{array}{l}0.29 \\
(0.26)\end{array}$ & $\begin{array}{l}0.24 \\
(0.33)\end{array}$ & $\begin{array}{l}0.32 \\
(0.26)\end{array}$ & $\begin{array}{l}0.21 \\
(0.34)\end{array}$ & $\begin{array}{l}0.21 \\
(0.30)\end{array}$ & $\begin{array}{l}0.09 \\
(0.27)\end{array}$ & $\begin{array}{l}0.39 \\
(0.51)\end{array}$ & $\begin{array}{l}0.27 \\
(0.30)\end{array}$ & $\begin{array}{l}0.30 \\
(0.50)\end{array}$ \\
\hline Wealth control & $\begin{array}{l}1.49^{b} \\
(0.73)\end{array}$ & $\begin{array}{l}1.54^{\mathrm{c}} \\
(0.78)\end{array}$ & $\begin{array}{l}1.54^{b} \\
(0.73)\end{array}$ & $\begin{array}{l}1.65^{\mathrm{b}} \\
(0.79)\end{array}$ & $\begin{array}{l}-0.24 \\
(0.49)\end{array}$ & $\begin{array}{l}-0.77 \\
(0.82)\end{array}$ & $\begin{array}{l}-0.63 \\
(0.86)\end{array}$ & $\begin{array}{l}-0.67 \\
(0.57)\end{array}$ & $\begin{array}{l}-0.73 \\
(0.75)\end{array}$ \\
\hline Observations & 35 & 35 & 35 & 35 & 24 & 24 & 24 & 24 & 24 \\
\hline MSE & 3.56 & 3.61 & 3.58 & 3.62 & 3.01 & 2.89 & 3.03 & 2.76 & 2.84 \\
\hline Adjusted $R$-Squared & 0.30 & 0.28 & 0.29 & 0.28 & 0.44 & 0.48 & 0.43 & 0.53 & 0.50 \\
\hline
\end{tabular}


Table 6

Budget/GDP-based public enforcement in horse race with private enforcement

In this table, we again present horse races between resource-based public enforcement and private enforcement variables, in this table using the budget/GDP-based (extended sample) to measure the intensity of public resource-based enforcement. Panel A uses market capitalization/GDP as the outcome variable, Panel B trading volume/GDP as the outcome variable, Panel C the number of domestic firms/population, and Panel D IPOs/GDP. We run five models with each of the four outcome variables. Columns 1 and 2 run the public enforcement variables, with resource-based enforcement alone first in column 1 , and then with formal public enforcement as measured by the securities regulators' powers in column 2 . Columns 3,4 , and 5 check for the robustness of the resource-based enforcement measure in horse races between public and private enforcement: i.e., the budget/ GDP-based resource variable runs against disclosure in column 3, then against liability in column 4, and then against both private enforcement measures in column 5 . We add three conditioning variables to each model: wealth, judicial efficiency, and anti-directors rights. The resource-based measure is significant in all 20 models, notably including those in column 5 with all of the private-oriented enforcement variables. Disclosure is often significant when run without resource-based enforcement, as seen in Table 5; it loses its significance in four of the eight trials when run against the budget/GDP-based indicator of public enforcement intensity, as seen in columns 3 and 5 of the four panels in this table. Liability standards turn negative in the face of the resource-based measure of public enforcement in two of the eight models. Liability is never significant with the sign expecte from prior work. Robust standard errors are in parentheses; the constant is not reported.

Panel A

$\underline{\text { Dependent variable }=\text { Stock market capitalization } / G D P}$

\section{Regulatory budget/GDP \\ (extended sample)}

Formal public enforcement

Disclosure

Liability standards

Anti-director rights (rev.)

Judicial efficiency

Wealth control

Observations

MSE

Adjusted $R$-Squared

$(1)$
$0.79^{b}$
$(0.33)$

(2)

$0.69^{\mathrm{b}}$

$(3)$
$0.73^{\mathrm{b}}$

$0.73^{\mathrm{b}}$

$(0.34)$

$(4)$
$0.79^{b}$

$0.79^{\mathrm{b}}$

$(5)$
$0.73^{b}$

$(0.35)$

$106.19^{\mathrm{c}}$

(54.41) $72.91^{\mathrm{b}}$

(30.31)

17.21

17.21
$(27.11)$

19.62

19.62
$(14.30)$

(14.30)

$-8.22$

(6.99)

$54.40^{\mathrm{b}}$

(25.53)

$72.55^{\mathrm{b}}$

(32.76)

0.79

$(27.37)$

(14.52)

$-8.38$

(7.21)

$53.20^{\mathrm{b}}$

$\begin{array}{llll}51.29 & 53.22 & 54.40 & 53.20 \\ (20.64) & (24.62) & (25.53) & (25.37)\end{array}$

Panel B

$\underline{\text { Dependent variable }=\text { Trading volume } / G D P}$

$\begin{array}{ccccc}(1) & (2) & (3) & (4) & (5) \\ 0.40^{\mathrm{a}} & 0.31^{\mathrm{a}} & 0.32^{\mathrm{b}} & 0.38^{\mathrm{a}} & 0.32^{\mathrm{b}}\end{array}$

$(0.13) \quad(0.10)-(0.13) \quad(0.13)$

$88.44^{\mathrm{b}}$

(39.05)

$\begin{array}{ccccc} & & 94.12^{\mathrm{b}} & & 85.39^{\mathrm{b}} \\ & & (34.24) & & (30.79) \\ & & & 38.59 & 19.27 \\ & & & (29.89) & (27.73) \\ 16.25^{\mathrm{c}} & 15.00^{\mathrm{b}} & 10.31 & 13.48 & 9.47 \\ (8.18) & (6.98) & (8.08) & (8.98) & (8.53) \\ -5.75 & -1.51 & -5.99 & -5.83 & -6.01 \\ (4.63) & (5.08) & (4.38) & (4.91) & (4.42) \\ 44.35^{\mathrm{a}} & 41.19^{\mathrm{a}} & 41.95^{\mathrm{a}} & 42.80^{\mathrm{a}} & 41.40^{\mathrm{a}} \\ (12.72) & (10.43) & (12.16) & (12.94) & (12.43)\end{array}$

$\begin{array}{ccccc}29 & 29 & 29 & 29 & 29 \\ 43.73 & 39.64 & 40.32 & 43.25 & 40.87 \\ 0.58 & 0.67 & 0.66 & 0.61 & 0.67\end{array}$

Panel C

Dependent variable $=$ Domestic firms $/$ population

$\begin{array}{cc}(1) & (2) \\ 0.023^{\mathrm{b}} & 0.020^{\mathrm{b}} \\ (0.009) & (0.009) \\ & 2.56 \\ & (2.50)\end{array}$

\section{(3) (4) (5)}

$0.022^{b}$

(0.010)

$0.022^{b}$

(0.009)

$0.022^{\mathrm{b}}$

(extended sample)

Formal public enforcement

Disclosure

1.15

(2.15)

Liability standards

Anti-director rights (rev.)

Judicial efficiency

Wealth control

$\begin{array}{ccccc}1.10^{\mathrm{b}} & 1.07^{\mathrm{b}} & 1.03^{\mathrm{c}} & 0.99^{\mathrm{c}} & 0.97^{\mathrm{c}} \\ (0.46) & (0.47) & (0.52) & (0.53) & (0.56) \\ -0.082 & 0.041 & -0.85 & -0.085 & -0.86 \\ (0.26) & (0.31) & (0.27) & (0.26) & (0.27) \\ 1.83^{\mathrm{b}} & 1.74^{\mathrm{b}} & 1.80^{\mathrm{b}} & 1.77^{\mathrm{b}} & 1.76^{\mathrm{b}} \\ (0.80) & (0.74) & (0.81) & (0.81) & (0.82) \\ & & & & \\ 29 & 29 & 29 & 29 & 29 \\ 2.41 & 2.38 & 2.45 & 2.42 & 2.47 \\ 0.59 & 0.62 & 0.60 & 0.61 & 0.61\end{array}$

Panel D

$\underline{\text { Dependent variable }=I P O S / G D P}$

$\begin{array}{llll}(2) & \text { (3) } \quad \text { (4) }\end{array}$

$\begin{array}{ccccc}(1) & (2) & (3) & (4) & \\ 0.036^{\mathrm{b}} & 0.046^{\mathrm{a}} & 0.037^{\mathrm{b}} & 0.040^{\mathrm{b}} & 0.040^{\mathrm{a}}\end{array}$

$\begin{array}{lllll}(0.015) & (0.014) & (0.015) & (0.014) & (0.013)\end{array}$

$-4.42$

(3.50)

$-1.50 \quad 0.47$

(4.66) (5.27)

(1.60) (1.95)

$\begin{array}{lllll}1.03 & 1.05 & 1.07 & 1.05 & 1.04^{\mathrm{C}}\end{array}$

$\begin{array}{lllll}1.0 .74) & (0.76) & (0.69) & (0.68) & (0.59)\end{array}$

$\begin{array}{lllll}-0.071 & -0.21 & 0.005 & 0.0013 & -0.20\end{array}$

$\begin{array}{lllll}(0.47) & (0.44) & (0.70) & (0.47) & (0.70)\end{array}$

$\begin{array}{lllll}1.48^{\mathrm{c}} & 1.33 & 1.35 & 1.27^{\mathrm{b}} & 1.30\end{array}$

$\begin{array}{lllll}(0.73) & (0.83) & (1.01) & (0.59) & (0.86)\end{array}$

$\begin{array}{lllll}21 & 21 & 21 & 21 & 21\end{array}$

$\begin{array}{ccccc}21 & 21 & 21 & 21 & 21 \\ 3.21 & 3.16 & 3.30 & 3.18 & 3.29 \\ 0.55 & 0.59 & 0.55 & 0.59 & 0.59\end{array}$ $-3.11^{\mathrm{c}} \quad-3.23$

Adjusted $R$-Squared

at $5 \%$; and c = significant at $10 \%$. 
Table 7

Distribution of coefficients on public enforcement and private enforcement variables in predicting four financial market size outcomes, when winsorizing and using robust regressions

In this table, we summarize the coefficients on the resource-based public and the private enforcement variables, with a view to testing for their robustness when influential observations are dampened by winsorizing and by using STATA's rreg command. Columns 1-3, in for $\mathrm{A}$, sum number of firms, and IPOS, vielding 24 regressions for the six samples and four outcomes. Columns $1-3$ in Panel A report the overall results for the three types of samples and column 4 summarizes those results with standard OLS regressions: The resource-based measures of public enforcement are significant $96 \%$ of the time and always positive. The private enforcement variable for disclosure is largely significant (in 54\% of the regressions) and usually positive (in $79 \%$ of the regressions) and occasionally negative (in $21 \%$ of the regressions). The liability index does less well: never positive and significant and negative more often than positive, sometimes significantly so. In Panel B, columns 5-8 summarize the effect of winsorizing (at the 0.1 level) the dependent variables and the resource-based

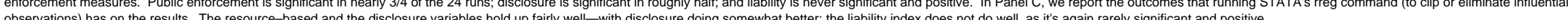

Panel A

Standard OLS regressions

Columns $1-4$ report the nature of the coefficients in 24 OLS regressions, with four financial market size variables as the outcomes and the six resource-based public
enforcement variables as the main independent variables

\begin{tabular}{|c|c|c|c|}
\hline (1) & (2) & (3) & (4) \\
\hline $\begin{array}{l}\text { Coefficients for } \\
\text { budgetGDP and } \\
\text { staffing/pop (basic) }\end{array}$ & $\begin{array}{l}\text { Coefficieints for } \\
\text { budgettGDP and } \\
\text { staffing(pop } \\
\text { (extended) }\end{array}$ & $\begin{array}{l}\text { Coefficieints for } \\
\text { budgettGDP and } \\
\text { staffing(pop } \\
\text { (extrapolated) }\end{array}$ & $\begin{array}{c}\text { Subtotal of } \\
\text { coefficients } \\
\text { all standard } \\
\text { OLS } \\
\text { regressions }\end{array}$ \\
\hline
\end{tabular}

Resource-based public enforcement coeficicients that are both positive and significan Positive coefficients

Cefficients that are both negative and significant

Disclosure index

Coefficients that are both positive and significan Positive coefficients

Coefficients that are both negative and significan

Liability index

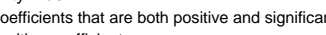

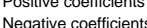

Coefficients that are both negative and significant

Anti-director rights index (revised)

(C) Positive coefficients
Negative coefficients

Coefficients that are both negative and significant

Judicial efficiency index

Defficients that are both positive and significan

Negative coefficieints
Coeficieints that are both negative and significan

$100 \%$
$100 \%$
$0 \%$
$0 \%$

$100 \%$

$88 \%$
$100 \%$

$96 \%$
$100 \%$
$0 \%$
$0 \%$

$\begin{array}{ll}63 \% & 50 \% \\ 88 \% & 75 \% \\ 13 \% & 25 \% \\ 0 \% & 0 \%\end{array}$

$50 \% \quad 54 \%$

$0 \% \quad 0 \%$

$25 \%$

$21 \%$

$\quad 0 \%$

$63 \%$
$100 \%$

$0 \%$

$63 \%$
$13 \%$

$67 \%$
$25 \%$

$0 \%$

$0 \%$
$25 \%$
$75 \%$

$75 \%$
$13 \%$
$0 \%$
$25 \%$
$75 \%$

\begin{tabular}{ll}
$0 \%$ & $0 \%$ \\
$75 \%$ & $42 \%$ \\
$25 \%$ & $58 \%$ \\
\hline
\end{tabular}

Panel B

eg regressio

Columns 5-8 report the nature of the coefficients in 24 OLS regressions, with 4 Columns 9-12 report the nature of the coefficients in 24 rreg regressions, with

four financia mat variables

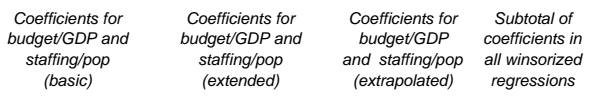

(9)

(10)

(11)

(12)

(basic) (extended) (extrapolated) regressions

staffing

$88 \%$
$100 \%$
$0 \%$
$0 \%$

$75 \%$
$100 \%$

$50 \%$
$88 \%$
$13 \%$
$0 \%$

$71 \%$
$96 \%$
$4 \%$
$0 \%$

$0 \%$

$0 \%$

$63 \%$
$83 \%$
$13 \%$
$0 \%$

$50 \%$
$88 \%$
$13 \%$

$0 \%$

$0 \%$

$0 \%$
$63 \%$

$63 \%$
$38 \%$
$13 \%$

$38 \%$
$63 \%$
$38 \%$

$\begin{array}{ccc}38 \% & 42 \% & 38 \% \\ 100 \% & 100 \% & 88 \% \\ 0 & 0 \% & 13 \%\end{array}$

$0 \%$
$88 \%$
$13 \%$

$88 \%$
$13 \%$
$0 \%$

$0 \%$
$63 \%$
$38 \%$
$0 \%$

$0 \%$
$88 \%$
$13 \%$
$0 \%$

$0 \%$
$63 \%$
$38 \%$
$4 \%$

$0 \%$
$50 \%$
$50 \%$
$0 \%$

$0 \%$
$63 \%$
$38 \%$
$0 \%$

$63 \%$
$38 \%$
$13 \%$

$58 \%$
$42 \%$
$4 \%$ 
Table 8

Regressions with dependent variables associated with private control

In this table, we examine resource-based public enforcement and private enforcement measures' association with variables related to private control. (These variables were outlined and highlighted in LLS, 2006.) Columns 1 and 2 look at the block premium, a variable indicative of the degree to which insiders can transfer value to themselves. Columns 3 and 4 measure access to equity. The outcome measured in 5 and 6 is ownership concentration. Columns 1, 3, and 5 use staffing/population (extended sample) as the resource-based measure of public enforcement. Columns 2, 4, and 6 use budget/GDP (extended sample). Disclosure is significant across all six outcomes and in the expected direction. Neither public enforcement nor the liability index predict these outcomes. Robust standard errors are in parentheses; the constant and the wealth control are not reported.

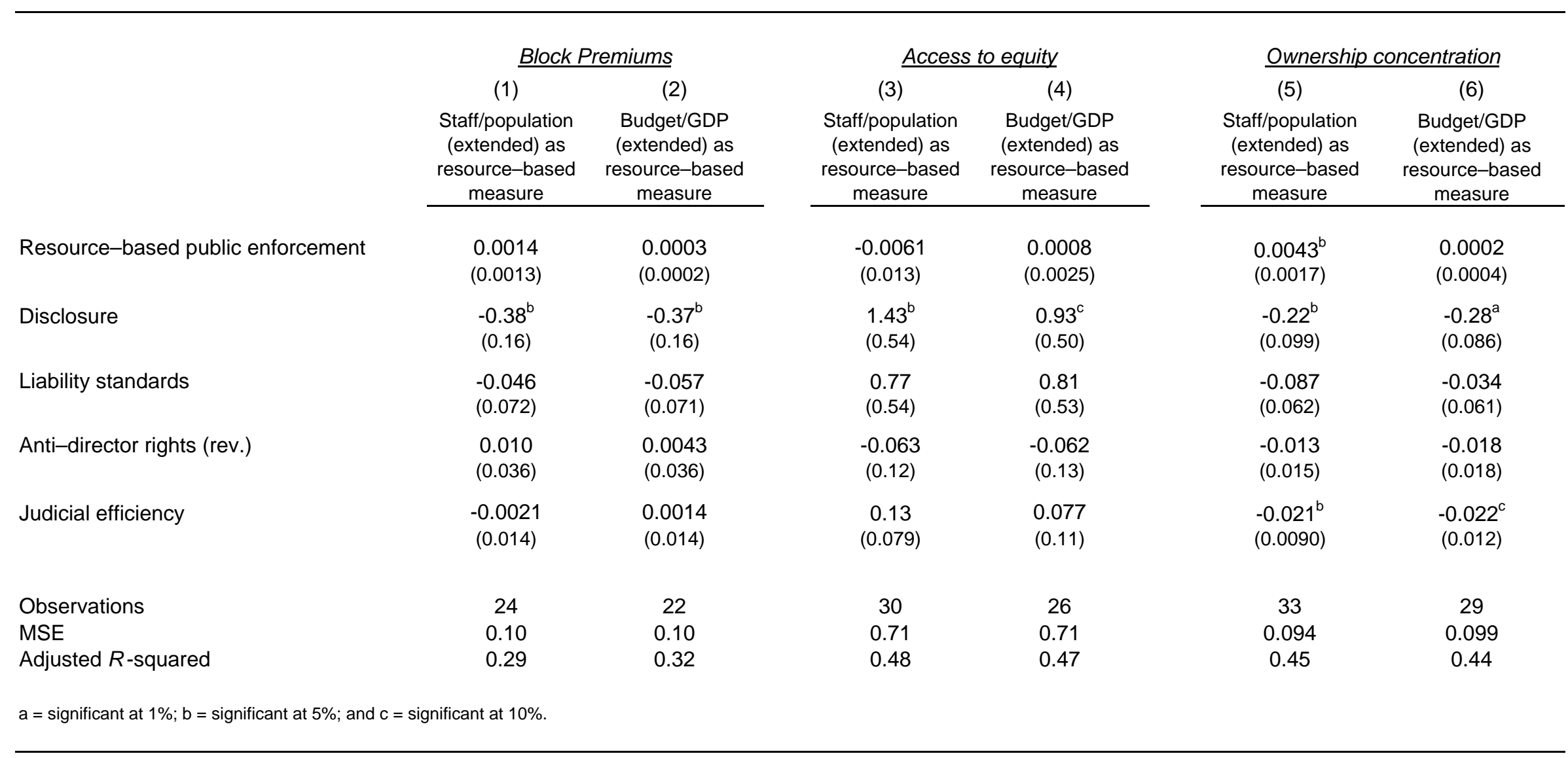


Table 9

Regressions with new World Bank indices as dependent variables

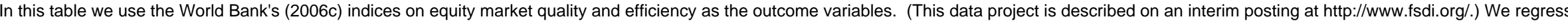

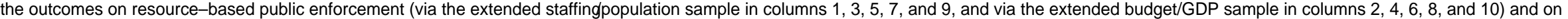

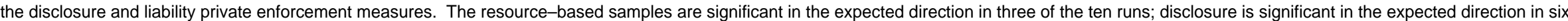

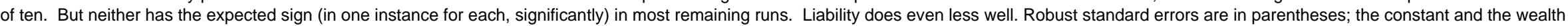
control are not reported.

\begin{tabular}{|c|c|c|c|c|c|c|c|c|c|c|}
\hline & \multicolumn{2}{|c|}{ Equity index } & \multicolumn{2}{|c|}{ Equity market size } & \multicolumn{2}{|c|}{$\underline{\text { Market access }}$} & \multicolumn{2}{|c|}{ Market efficiency } & \multicolumn{2}{|c|}{ Market stability } \\
\hline & (1) & (2) & (3) & (4) & (5) & (6) & (7) & (8) & (9) & (10) \\
\hline & $\begin{array}{c}\text { Staff/ } \\
\text { population } \\
\text { (extended) as } \\
\text { resource-base } \\
\text { d measure } \\
\end{array}$ & $\begin{array}{c}\text { Budget/GDP } \\
\text { (extended) as } \\
\text { resource-base } \\
\text { d measure } \\
\end{array}$ & $\begin{array}{c}\text { Staff/ } \\
\text { population } \\
\text { (extended) as } \\
\text { resource-base } \\
\text { d measure } \\
\end{array}$ & $\begin{array}{c}\text { Budget/GDP } \\
\text { (extended) as } \\
\text { resource-base } \\
\text { d measure } \\
\end{array}$ & $\begin{array}{c}\text { Staff/ } \\
\text { population } \\
\text { (extended) as } \\
\text { resource-base } \\
\text { d measure } \\
\end{array}$ & $\begin{array}{c}\text { Budget/GDP } \\
\text { (extended) as } \\
\text { resource-base } \\
\text { d measure } \\
\end{array}$ & $\begin{array}{c}\text { Staff/ } \\
\text { population } \\
\text { (extended) as } \\
\text { resource-base } \\
\text { d measure } \\
\end{array}$ & $\begin{array}{l}\text { Budget/GDP } \\
\text { (extended) as } \\
\text { resource-base } \\
\text { d measure } \\
\end{array}$ & $\begin{array}{c}\text { Staff/ } \\
\text { population } \\
\text { (extended) as } \\
\text { resource-base } \\
\text { d measure } \\
\end{array}$ & $\begin{array}{c}\text { Budget/GDP } \\
\text { (extended) as } \\
\text { resource-base } \\
\text { d measure } \\
\end{array}$ \\
\hline Resource-based public enforcement & $\begin{array}{l}0.026^{\mathrm{b}} \\
(0.013)\end{array}$ & $\begin{array}{c}0.0032 \\
(0.0020)\end{array}$ & $\begin{array}{c}0.12^{\mathrm{b}} \\
(0.054)\end{array}$ & $\begin{array}{c}0.017^{\mathrm{b}} \\
(0.0069)\end{array}$ & $\begin{array}{l}-0.0018 \\
(0.015)\end{array}$ & $\begin{array}{c}0.0004 \\
(0.0022)\end{array}$ & $\begin{array}{l}-0.015 \\
(0.016)\end{array}$ & $\begin{array}{l}-0.0051^{\mathrm{c}} \\
(0.0027)\end{array}$ & $\begin{array}{l}-0.0037 \\
(0.0081)\end{array}$ & $\begin{array}{c}0.0008 \\
(0.0008)\end{array}$ \\
\hline Disclosure & $\begin{array}{l}0.98^{\mathrm{b}} \\
(0.41)\end{array}$ & $\begin{array}{l}0.98^{\mathrm{c}} \\
(0.49)\end{array}$ & $\begin{array}{l}3.31^{\mathrm{a}} \\
(0.91)\end{array}$ & $\begin{array}{l}3.28^{\mathrm{a}} \\
(1.17)\end{array}$ & $\begin{array}{l}1.51^{\mathrm{C}} \\
(0.85)\end{array}$ & $\begin{array}{l}1.86^{\mathrm{b}} \\
(0.86)\end{array}$ & $\begin{array}{l}-1.51 \\
(0.91)\end{array}$ & $\begin{array}{l}-1.00 \\
(1.12)\end{array}$ & $\begin{array}{c}0.62 \\
(0.79)\end{array}$ & $\begin{array}{l}-0.25 \\
(0.52)\end{array}$ \\
\hline Liability standards & $\begin{array}{l}0.092 \\
(0.45)\end{array}$ & $\begin{array}{c}0.42 \\
(0.39)\end{array}$ & $\begin{array}{l}-1.14 \\
(1.28)\end{array}$ & $\begin{array}{l}0.081 \\
(1.01)\end{array}$ & $\begin{array}{l}0.047 \\
(0.68)\end{array}$ & $\begin{array}{c}0.15 \\
(0.68)\end{array}$ & $\begin{array}{l}0.88 \\
(0.74)\end{array}$ & $\begin{array}{c}0.75 \\
(0.69)\end{array}$ & $\begin{array}{c}0.73 \\
(0.43)\end{array}$ & $\begin{array}{l}0.68^{\mathrm{C}} \\
(0.40)\end{array}$ \\
\hline Anti-directors rights (rev.) & $\begin{array}{c}0.16 \\
(0.12)\end{array}$ & $\begin{array}{l}0.17 \\
(0.14)\end{array}$ & $\begin{array}{c}0.27 \\
(0.32)\end{array}$ & $\begin{array}{c}0.42 \\
(0.36)\end{array}$ & $\begin{array}{c}0.33 \\
(0.20)\end{array}$ & $\begin{array}{c}0.34 \\
(0.23)\end{array}$ & $\begin{array}{c}0.11 \\
(0.24)\end{array}$ & $\begin{array}{c}0.0011 \\
(0.20)\end{array}$ & $\begin{array}{l}-0.081 \\
(0.084)\end{array}$ & $\begin{array}{l}-0.096 \\
(0.080)\end{array}$ \\
\hline Judicial efficiency & $\begin{array}{l}0.018 \\
(0.053)\end{array}$ & $\begin{array}{l}-0.042 \\
(0.068)\end{array}$ & $\begin{array}{l}-0.11 \\
(0.15)\end{array}$ & $\begin{array}{l}-0.35 \\
(0.21)\end{array}$ & $\begin{array}{l}0.085 \\
(0.087)\end{array}$ & $\begin{array}{c}0.051 \\
(0.098)\end{array}$ & $\begin{array}{l}0.034 \\
(0.10)\end{array}$ & $\begin{array}{l}0.086 \\
(0.13)\end{array}$ & $\begin{array}{l}0.061 \\
(0.048)\end{array}$ & $\begin{array}{l}0.048 \\
(0.053)\end{array}$ \\
\hline Observations & 33 & 29 & 33 & 29 & 33 & 29 & 32 & 29 & 33 & 29 \\
\hline MSE & 0.60 & 0.62 & 1.67 & 1.73 & 1.04 & 1.07 & 1.08 & 1.02 & 0.54 & 0.43 \\
\hline Adjusted $R$-squared & 0.66 & 0.66 & 0.61 & 0.61 & 0.19 & 0.17 & 0.43 & 0.53 & 0.28 & 0.28 \\
\hline
\end{tabular}


Table 10

Distribution of coefficients on common law dummy, after controlling for public and private enforcement measures

This table reports the residual value of the common law dummy, after one controls for public enforcement, as measured with the values reported in Table 2, and private enforcement, using the measures indicated in Table 1 . The outcomes are again the same market size measures: stock market capitalization, trading volume, number of domestic firms, and IPOs. This set of specificalions yields 24 models. Columns 1-4 report the standard OLS regressions, with the four financial market breadth variables as the outcomes. Column 1 reports the distribution of coefficients for the common law dummy, using the basic samples for staffing / population and for budget / GDP as the public enforcement measures. Column 2 does the same, but uses the extended resource-based measures. positive and significant, is often netative, and is oclesionally ne cotive and significant. The resource-based public enforcement variables are significant in nealy all of the regressions; disclosure is significant in half; liability is never positive and significant.

\begin{tabular}{|c|c|c|c|c|}
\hline & \multicolumn{4}{|c|}{$\begin{array}{l}\text { Columns (1)-(4) report the nature of the coefficients in } 24 \text { OLS regressions, with four financial } \\
\text { market size variables as the outcomes and the six resource-based public enforcement variables as } \\
\text { the main independent variables }\end{array}$} \\
\hline & $\begin{array}{c}(1) \\
\text { Coefficients for } \\
\text { budget/GDP and } \\
\text { staffing/population } \\
\text { (basic) }\end{array}$ & $\begin{array}{c}(2) \\
\text { Coefficients for } \\
\text { budget/GDP and } \\
\text { staffing/population } \\
\text { (extended) }\end{array}$ & $\begin{array}{c}(3) \\
\text { Coefficients for } \\
\text { budget/GDP and } \\
\text { staffing/population } \\
\text { (extrapolated) }\end{array}$ & $\begin{array}{c}\text { (4) } \\
\text { Total of } \\
\text { coefficients in all } \\
\text { standard OLS } \\
\text { regressions } \\
\end{array}$ \\
\hline \multicolumn{5}{|l|}{ Resource-based public enforcement } \\
\hline Coefficients that are both positive and significant & $100 \%$ & $100 \%$ & $88 \%$ & $96 \%$ \\
\hline Positive coefficients & $100 \%$ & $100 \%$ & $100 \%$ & $100 \%$ \\
\hline Negative coefficients & $0 \%$ & $0 \%$ & $0 \%$ & $0 \%$ \\
\hline Coefficients that are both negative and significant & $0 \%$ & $0 \%$ & $0 \%$ & $0 \%$ \\
\hline \multicolumn{5}{|l|}{ Common law dummy } \\
\hline Coefficients that are both positive and significant & $0 \%$ & $0 \%$ & $0 \%$ & $0 \%$ \\
\hline Positive coefficients & $25 \%$ & $13 \%$ & $13 \%$ & $17 \%$ \\
\hline Negative coefficients & $75 \%$ & $88 \%$ & $88 \%$ & $83 \%$ \\
\hline 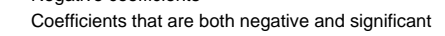 & $25 \%$ & $25 \%$ & $13 \%$ & $21 \%$ \\
\hline \multicolumn{5}{|l|}{ Disclosure index } \\
\hline Coefficients that are both positive and significant & $50 \%$ & $50 \%$ & $50 \%$ & $50 \%$ \\
\hline Positive coefficients & $75 \%$ & $88 \%$ & $88 \%$ & $83 \%$ \\
\hline Negative coefficients & $25 \%$ & $13 \%$ & $13 \%$ & $17 \%$ \\
\hline Coefficients that are both negative and significant & $0 \%$ & $0 \%$ & $0 \%$ & $0 \%$ \\
\hline \multicolumn{5}{|l|}{ Liability index } \\
\hline Coefficients that are both positive and significant & $0 \%$ & $0 \%$ & $0 \%$ & $0 \%$ \\
\hline Positive coefficients & $25 \%$ & $25 \%$ & $38 \%$ & $29 \%$ \\
\hline Negative coefficients & $75 \%$ & $75 \%$ & $63 \%$ & $71 \%$ \\
\hline Coefficients that are both negative and significant & $38 \%$ & $25 \%$ & $13 \%$ & $25 \%$ \\
\hline \multicolumn{5}{|l|}{ Anti-director rights index (revised) } \\
\hline Coefficients that are both positive and significant & $63 \%$ & $38 \%$ & $38 \%$ & $46 \%$ \\
\hline Positive coefficients & $100 \%$ & $100 \%$ & $100 \%$ & $100 \%$ \\
\hline Negative coefficients & $0 \%$ & $0 \%$ & $0 \%$ & $0 \%$ \\
\hline Coefficients that are both negative and significant & $0 \%$ & $0 \%$ & $0 \%$ & $0 \%$ \\
\hline \multicolumn{5}{|l|}{ Judicial efficiency index } \\
\hline Coefficients that are both positive and significant & $0 \%$ & $0 \%$ & $0 \%$ & $0 \%$ \\
\hline Positive coefficients & $38 \%$ & $50 \%$ & $63 \%$ & $50 \%$ \\
\hline Negative coefficients & $63 \%$ & $50 \%$ & $38 \%$ & $50 \%$ \\
\hline Coefficients that are both negative and significant & $0 \%$ & $0 \%$ & $0 \%$ & $0 \%$ \\
\hline
\end{tabular}



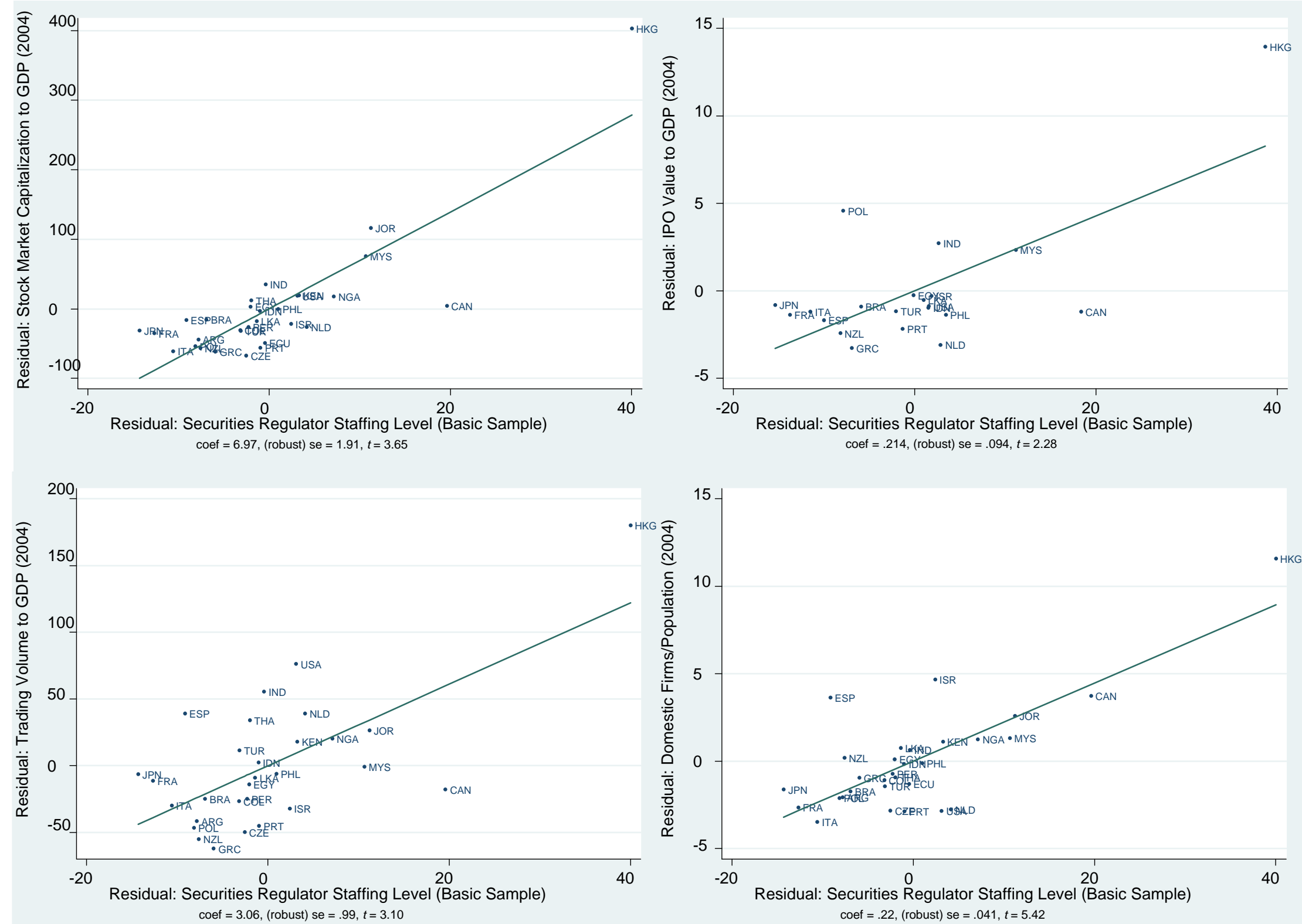

Fig. 1. Residual plot of financial market size on securities regulator staffing (extended sample). These figures plot the residuals of four financial market outcomes on the residual for the regulators' staffing levels (extended sample). The model specification is of the form in Table 5, column 9. Independent variables are disclosure, liability standards, anti-director rights, a wealth control, and judicial efficiency. 
52
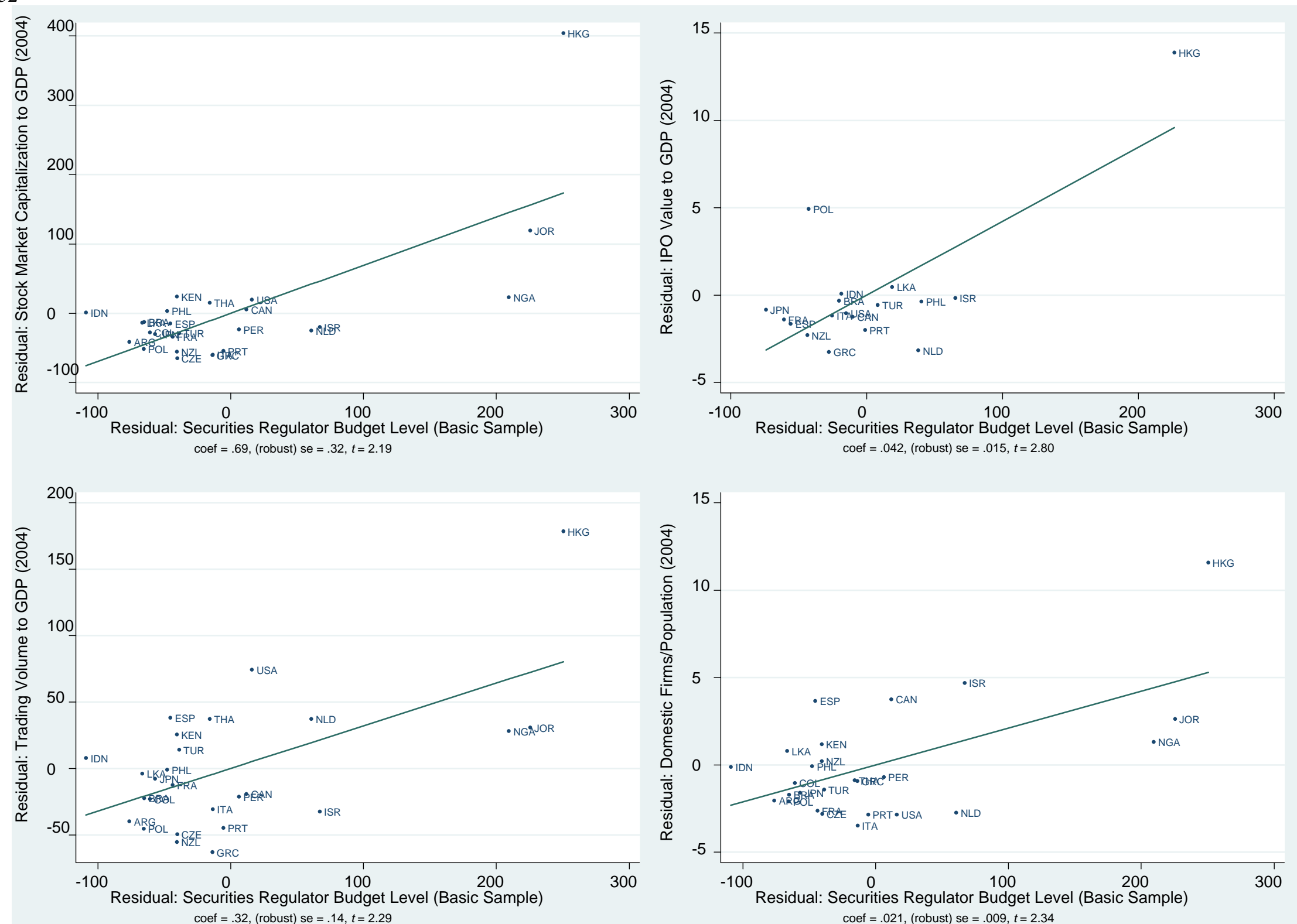

Fig. 2. Residual plot of financial market size on securities regulator budget (extended sample). These figures plot the residuals of four financial market outcomes on the residual for the regulators' budget levels (extended sample). The model specification is of the form in Table 6, column 5. Independent variables are disclosure, liability standards, anti-director rights, a wealth control, and judicial efficiency. 